\title{
Learning Together for and with the Martuwarra Fitzroy River
}

\author{
Rosemary Hill ${ }^{1,2}$ - Pia Harkness ${ }^{1}$ - Nat Raisbeck-Brown ${ }^{1} \cdot$ Ilisapeci Lyons ${ }^{1}$ · Jorge G. Álvarez-Romero ${ }^{2}$. \\ Milena Kiatkoski Kim ${ }^{3}$. Dennis Chungalla ${ }^{4} \cdot$ Heather Wungundin ${ }^{4} \cdot$ Mary Aiken $^{4}$. Jean Malay ${ }^{4}$. \\ Bernadette Williams ${ }^{4} \cdot$ Rachel Buissereth ${ }^{5}$. Tim Cranbell ${ }^{4}$. Josephine Forrest ${ }^{4}$. Marmingee Hand ${ }^{4} \cdot$ Ross James $^{4}$. \\ Elizabeth Jingle ${ }^{4}$. Olive Knight ${ }^{4,6} \cdot$ Nathan Lennard $^{4}$. Valerie Lennard ${ }^{4} \cdot$ lleen Malay ${ }^{4} \cdot$ Lindsay Malay $^{4}$. \\ Wallace Midmee ${ }^{4}$. Stuart Morton ${ }^{4}$. Chloe Nulgit ${ }^{4}$. Patricia Riley ${ }^{4}$. Ina Shadforth ${ }^{4}$. Jane Bieundurry ${ }^{4}$. \\ George Brooking ${ }^{4}$. Sherika Brooking ${ }^{4}$. Willy Brumby ${ }^{4}$. Victor Bulmer ${ }^{4}$. Virgil Cherel ${ }^{4}$. Ashley Clifton ${ }^{4}$. \\ Sam Cox ${ }^{4}$ Matt Dawson ${ }^{4}$. Cissy Gore-Birch ${ }^{4}$ John Hill ${ }^{5}$. Alistair Hobbs ${ }^{4}$. Duran Hobbs ${ }^{4}$. Camelia Juboy ${ }^{4}$. \\ Patricia Juboy ${ }^{4}$. Annette Kogolo ${ }^{4}$. Sarah Laborde ${ }^{7}$. Barry Lennard ${ }^{4}$. Con Lennard ${ }^{4}$. Deon Lennard ${ }^{4}$. \\ Nelita Malay ${ }^{4} \cdot$ Zenneth Malay ${ }^{4} \cdot$ David Marshall ${ }^{4} \cdot$ Herbert Marshall ${ }^{4} \cdot$ Lezeka Millindee $^{4} \cdot$ Diane Mowaljarlai $^{4}$. \\ Andrea Myers ${ }^{4}$. Thomas Nnarda ${ }^{4}$. Joy Nuggett ${ }^{4}$. Lloyd Nulgit ${ }^{4}$. Pansy Nulgit ${ }^{4}$. Anne Poelina ${ }^{4} \cdot$ Daniel Poudrill $^{4}$. \\ Joe Ross ${ }^{4}$. Jimmy Shandley ${ }^{4}$. Roly Skander ${ }^{5}$. Sandy Skeen ${ }^{4}$. Gordon Smith ${ }^{4}$. Mervyn Street ${ }^{4}$. Pauline Thomas ${ }^{4}$. \\ Bronson Wongawol ${ }^{4} \cdot$ Harry Yungabun ${ }^{4} \cdot$ Arosha Sunfly $^{4,8} \cdot$ Cyntala Cook $^{4,8} \cdot$ Kaunell Shaw $^{4,8} \cdot$ Taliesha Collard $^{4,8}$. \\ Yvonne Collard ${ }^{4,8}$
}

Received: 21 December 2020 / Accepted: 10 June 2021 / Published online: 29 July 2021

(c) The Author(s) 2021

\begin{abstract}
Co-production across scientific and Indigenous knowledge systems has become a cornerstone of research to enhance knowledge, practice, ethics, and foster sustainability transformations. However, the profound differences in world views and the complex and contested histories of nation-state colonisation on Indigenous territories, highlight both opportunities and risks for Indigenous people when engaging with knowledge co-production. This paper investigates the conditions under which knowledge co-production can lead to improved Indigenous adaptive environmental planning and management among remote land-attached Indigenous peoples through a case study with ten Traditional Owner groups in the Martuwarra (Fitzroy River) Catchment in Western Australia's Kimberley region. The research team built a 3D map of the river and used it, together with an interactive table-top projector, to bring together both scientific and Indigenous spatial knowledge. Participatory influence mapping, aligned with Traditional Owner priorities to achieve cultural governance and management planning goals set out in the Fitzroy River Declaration, investigated power relations. An analytical framework, examining underlying mechanisms of social learning, knowledge promotion and enhancing influence, based on different theories of change, was applied to unpack the immediate outcomes from these activities. The analysis identified that knowledge co-production activities improved the accessibility of the knowledge, the experiences of the knowledge users, strengthened collective identity and partnerships, and strengthened Indigenous-led institutions. The focus on cultural governance and management planning goals in the Fitzroy River Declaration enabled the activities to directly affect key drivers of Indigenous adaptive environmental planning and management - the Indigenous-led institutions. The nation-state arrangements also gave some support to local learning and decision-making through a key Indigenous institution, Martuwarra Fitzroy River Council. Knowledge co-production with remote land-attached Indigenous peoples can improve adaptive environmental planning and management where it fosters learning together, is grounded in the Indigenous-led institutions and addresses their priorities.
\end{abstract}

Keywords Indigenous $\cdot$ Co-production $\cdot$ Institutions $\cdot$ Northern Australia $\cdot$ Rivers

Handledby Kirsten Maclean, CSIRO, Australia.

Extended author information available on the last page of the article 


\section{Introduction}

Knowledge co-production, collaboration that brings together different sources and types of knowledge to address an issue, has become a cornerstone of research to foster sustainability transformations (Armitage et al. 2011; Wyborn et al. 2019). Weaving scientific and Indigenous ${ }^{1}$ knowledge is particularly important for environmental governance within the substantial proportion of the world's land surface managed by Indigenous peoples (Mistry and Berardi 2016; Garnett et al. 2018). In Australia, environmental governance or cogovernance with and by Indigenous peoples occurs over more than forty percent of the continent (Metcalfe and Bui 2017). Knowledge co-production can improve Indigenous peoples' adaptive management of these traditional territories and thereby deliver environmental, cultural, social and economic outcomes (Ens et al. 2016; Jarvis et al. 2018; Zurba et al. 2019; McKemey et al. 2020). Nevertheless, weaving Indigenous and scientific knowledge encounters many challenges: the mis-match between text-based formats of science and the ritual, ceremonial, song, symbolic and visual manifestations of Indigenous knowledge; the lack of adequate protection for Indigenous intellectual and cultural rights; the relative scarcity of cross-cultural tools for knowledge coproduction that account for epistemological and ontological differences; and the ongoing impacts of colonial histories on institutions for local learning and decision-making (Zurba et al. 2019; Hill et al. 2020). This paper investigates the conditions under which knowledge co-production can foster impacts that improve Indigenous adaptive environmental planning and management among remote land-attached Indigenous peoples, based on a case study with ten Traditional Owner ${ }^{2}$ groups in the Martuwarra (Fitzroy River) basin of Western Australia, hereafter 'Fitzroy catchment' (Douglas et al. 2019).

Participatory mapping can co-create 'boundary objects'such as drawings, artwork, maps and models- defined here as objects that are valued on both sides of the boundary between Indigenous and scientific knowledge systems for their capacity to support communication, mutual understanding and cooperation (Cash and Moser 2000; Zurba et al. 2019). Cross-cultural projects between scientists and Indigenous communities have demonstrated that such boundary objects can be powerful tools to facilitate dialogue, learning

\footnotetext{
${ }^{1}$ Indigenous is capitalised throughout when used, either as an adjective or a noun, to refer to Indigenous people, following the accepted norm in Australia and New Zealand (Johnson et al. 2007).

2 Traditional Owner/s is used throughout when referring to Indigenous people with traditional rights and interests to lands and waters in the Fitzroy catchment, in accordance with their preferences. They are Indigenous self-determined nations who hold native title rights under Australian law.
}

and enhanced cooperation in environmental planning and management (Zurba et al. 2019). Influence mapping, for example, supports Indigenous participants to make drawings of social networks and thereby reveal how groups mobilise power in multi-level governance systems, and use this knowledge to jointly design strategies that advance Indigenous goals (Schiffer and Hauck 2010; Hauck et al. 2015). Spatial mapping approaches to support Indigenous goals include: land-use and occupancy mapping (Tobias 2000); cross-cultural mapping marine environments (Davies et al. 2020); constructing 3-dimensional (3D) maps of landscapes (Rambaldi et al. 2007; Banaynal and Dwamena 2011); and using augmented 3D-printed landscapes with projected spatial data (Fisher et al. 2019). Nevertheless, Indigenous people argue that knowledge co-production activities need to recognise their roles as self-determining nations with rights and the responsibility to lead application of their knowledge systems in environmental decision-making (Latulippe and Klenk 2020).

In Australia, the nation-state has sought to accommodate Indigenous rights primarily through renewed forms of legal and political recognition, including treaties, settlements, market-based instruments and rules in environmental and water planning legislation (Jackson 2018). Institutions arising from these recognition regimes, similar to other developed world contexts such as Canada and the USA, often remain colonial in their substance, based on patterns of domination which reinforce power asymmetries, rather than the reciprocal relations and obligations characterising Indigenous ways of living (Coulthard 2014; Whyte 2020). Aligning recognition regimes with Indigenous self-organised institutions for decision-making can reframe environmental planning and management to overcome these ongoing colonial patterns of domination and subordination (Carr et al. 2017; Hemming et al. 2017). Facilitating Indigenous-led processes for decision-making in turn helps create the new relationships based on negotiation, consent, trust, consensus, accountability, and reciprocity, which are required for effective and fair decision-making processes (Hemming et al. 2017; Jackson 2018; AIATSIS 2020; Whyte 2020). However, little is known about the conditions under which knowledge co-production supports these positive outcomes with remote land-attached Indigenous peoples (Hill et al. 2020).

Here a team of scientists and Traditional Owners from ten different groups of the Fitzroy catchment in the Kimberley Region of Western Australia set out to test knowledge co-production through spatial and non-spatial participatory mapping aligned closely with their Indigenous adaptive environment management institutions and initiatives. We posed the question "under what conditions can knowledge co-production lead to impacts that improve Indigenous 
Table 1 Traditional Owner groups, native title determinations and organisations involved in the project

\begin{tabular}{|c|c|c|}
\hline${ }^{\mathrm{a}}$ Group & ${ }^{b}$ Native title determinations (NTD) and registered claims & Organisations ${ }^{\mathrm{c}}$ representing the groups' interests \\
\hline Bunuba & $\begin{array}{l}4 \text { NTDs: Bunuba, Bunuba People \#2 Part A, Bunuba Part B, } \\
\text { Bunuba \#2 Part B }\end{array}$ & Bunuba Dawangarri Aboriginal Corporation \\
\hline Gooniyandi & $\begin{array}{l}3 \text { NTDs: Gooniyandi Combined \#2; Yarrangi Riwi Yoowarni } \\
\text { Gooniyandi People; Giniyjawarrni Yoowaniya Riwi }\end{array}$ & $\begin{array}{l}\text { Gooniyandi Aboriginal Corporation; Giniyjawar- } \\
\text { rni Yoowaniya Riwi Aboriginal Corporation }\end{array}$ \\
\hline Jaru & 1 NTD: Jaru & Jaru Claimant Group represented by the KLC \\
\hline Kija & 2 NTDs: Ngarrawanji; Yurriyangem Taam & $\begin{array}{l}\text { Kija Claimant Groups (Ngarrawanji and Yur- } \\
\text { riyangem Taam) represented by the KLC }\end{array}$ \\
\hline Kurungal & 1 NTD: Kurungal & Tiya Tiya Aboriginal Corporation \\
\hline Nyikina Mangala & 2 NTDs: Nyikina Mangala; Nyikina Mangala \#2 & Walalakoo Aboriginal Corporation \\
\hline Warrwa & 2 Claims: Warrwa Combined; Warrwa Mawadjala Gadjidgar & Warrwa Claimant Group represented by the KLC \\
\hline Wilinggin & $\begin{array}{l}1 \text { NTD: Wanjina-Wunggurr Wilinggin Native Title Determina- } \\
\text { tion No } 1\end{array}$ & Wilinggin Aboriginal Corporation \\
\hline Yi-Martuwarra Ngurrara & 2 NTDs: Yi-Martuwarra Ngurrara Part A; Ngurrara Part A & Yanunijarra Aboriginal Corporation \\
\hline Yungngora & 1 NTD: Noonkanbah & Yungngora Aboriginal Corporation \\
\hline
\end{tabular}

${ }^{\text {a }}$ The group corresponds to the name of the self-determined nations or Indigenous peoples associated with the noted NTDs or registered claim(s) that overlap the boundaries of the Fitzroy basin (Fig. 1). In most cases, the name corresponds with the main language(s) spoken by the group, but not always (e.g. Wilinggin: Ungarinyin, Yi-Martuwarra Ngurrara: Walmajarri).

${ }^{b}$ Some groups include several self-identified independent sub-groups recognised by the names of the individual NTD/Claim areas, such as the three Gooniyandi and two Kija sub-groups. In other cases, the different native title areas correspond to sections of the lands and waters corresponding to the same group (e.g. Bunuba, Nyikina Mangala), which were claimed/determined at different points in time.

${ }^{\mathrm{c}}$ The name of the organisation corresponds to the Registered Native Title Bodies Corporate (RNTBC), often referred to as a Prescribed Body Corporate (PBC) of the group, which are have prescribed functions under the Native Title Act 1993 to hold, protect and manage determined native title areas on behalf of the native title holders. During the project, Jaru, Kija and Warrwa peoples were represented by their corresponding native title claimant groups through their representative body the Kimberley Land Council. The Wilinggin Aboriginal Corporation is the agent of the Wanjina-Wunggurr (Native Title) Aboriginal Corporation in relation to the interests of the Ngarinyin people and activities on Wilinggin Country, which corresponds to the native title area overlapping the Fitzroy basin.

adaptive environmental planning and management by remote land-attached Indigenous peoples?".

The project goal was identified through a collaborative priority setting exercise (Hill et al. 2016), and progressed in two stages. Stage one commenced with a project logic that linked proposed knowledge co-production activities with envisaged impacts. The subsequent co-production activities used three mechanisms for impact: knowledge promotion; social learning; and enhancing influence. In stage two, progress towards the desired outcomes and impacts was analysed. The remaining paper is structured as follows. Methods are presented first, including the history and geography of the case study site, the action coresearch and participatory mapping methods, and then the framework for analysis based on literature review. The results section presents findings from stage one, the knowledge co-production activities, followed by the results from stage two, the analysis of contributions to the immediate outcomes and envisaged overall impact. The paper concludes with identification of three conditions under which knowledge co-production leads to improved Indigenous adaptive environmental planning and management. It highlights how the nation-state and the Indigenous institutional contexts affect and have been affected by the project.

\section{Methods}

\section{Case study history and geography}

The Martuwarra (Fitzroy River) in the Kimberley region of Western Australia connects ten major Traditional Owner groups, whose traditional lands are within or overlap the basin's boundary (Table 1, Fig. 1a and b), and where at least nine Indigenous languages ${ }^{3}$ are still widely spoken (McGregor 2004). Traditional Owners' lore and law describes how the region has been inhabited since time immemorial, with one occupation site dated at more than 47,000 years, and the resulting social-cultural-ecological system is characterized by the strong interdependence between Country and people (Toussaint et al. 2001; Vigilante 2001; Griffiths et al. 2011; Maloney et al. 2018; Poelina et al. 2019).

The globally significant cultural and natural values of the area, partly recognised through the West Kimberley National Heritage Place listing covering 34\% of the catchment, have been shaped over millennia by Traditional Owners' active

\footnotetext{
${ }^{3}$ Bunuba, Gooniyandi, Jaru, Kija, Nyikina, Mangala, Ungarinyin, Walmajarri, Warrwa.
} 

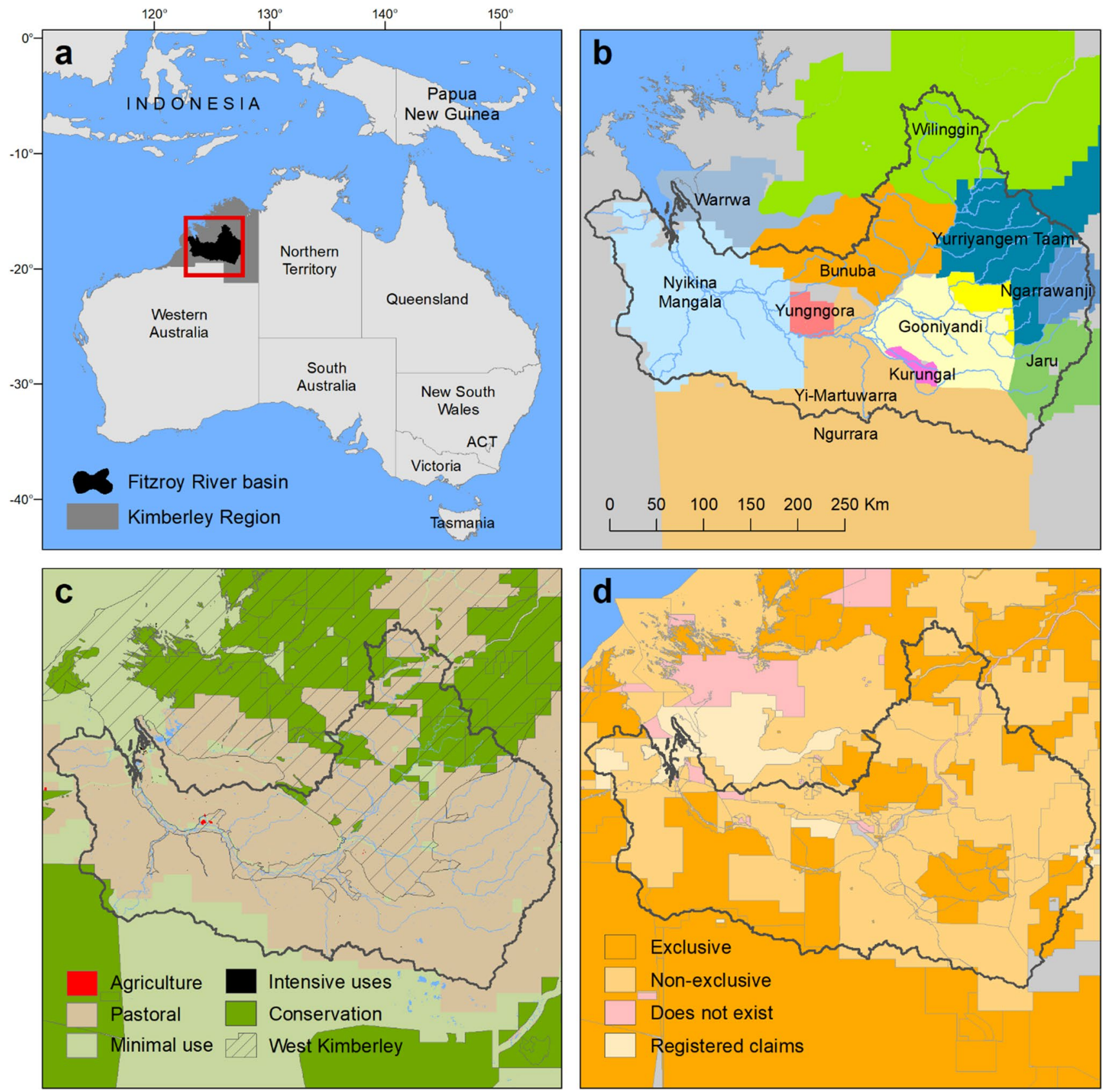

Fig. 1 Case study area. a Location of the Martuwarra (Fitzroy River) basin in the Kimberley Region of north Western Australia; according to Traditional Owners the basin includes the Fraser River, which also drains into the King Sound. b Land boundaries of the ten major Traditional Owner groups of the Martuwarra, based on 17 Native Title Determinations (Table 2). c Major land uses, conservation areas and boundaries of the West Kimberley National Heritage Place. d Out-

management (e.g. traditional burning), use (e.g. ceremony, medicinal, fishing), and protection of land and water following customary law and practices (Vigilante 2001; Jackson et al. 2012; Maloney et al. 2018; Poelina et al. 2019).

Following the arrival of the first European settlers, around 1880, the predominant use of the Fitzroy basin quickly

comes of the Native Title Determinations, including exclusive and non-exclusive Native Title rights. Data sources: Catchment Scale Land Use Mapping for Western Australia 2008-2017, Collaborative Australian Protected Areas Database 2018, and National Native Title Tribunal Data File Geodatabase (www.nntt.gov.au; data extracted on 11/09/2020); see details in Supplementary Table S1

shifted to extensive livestock grazing (currently $81 \%$ of the basin), along with small areas of irrigated agriculture $(0.05 \%)$ and other intensive uses $(0.2 \%)$, such as roads, housing, and mining (Fig. 1c). Today, most of the basin retains its native vegetation ( 99.7\%), including almost $10 \%$ protected under diverse conservation schemes. Beyond agricultural 
uses, the local Indigenous customary economy is vital to the 6000 Indigenous people in the catchment, who live in two major towns (Derby and Fitzroy Crossing) and 48 remote Indigenous communities (Jackson et al. 2012, 2014; Jackson 2015; ABS 2016; Petheram et al. 2018; DPLH 2020). The land tenure is primarily Crown leasehold land or reserves, and virtually the entire basin (98\%) is subject to Indigenous native title rights under the Australian Commonwealth's Native Title Act 1993. Within this area, Traditional Owners hold exclusive (i.e. possession of an area to the exclusion of all others) and non-exclusive (e.g. access and use the land for fishing, ceremony or camping) rights over $32 \%$ and $63 \%$ of the basin, respectively (Fig. 1d). Non-exclusive native title rights co-exist with pastoral, conservation, and mining interests, which contribute to the complex environmental governance of the region.

\section{Action co-research}

Action co-research in the project brought Traditional Owners and researchers together over a five-year period from 2015-2020 through multiple iterations of action learning cycles: action, observation/reflection, learn/plan (Fig. 2, Fig. 3). A desired real-world sustainability transformation to current environmental planning management across northern Australia was identified by the Indigenous-majority steering group for the project as: "Indigenous people are empowered to look after Country our way; and Improved environmental conditions and multiple social, cultural and economic benefits come from effective Indigenous adaptive management of Country" (Poelina et al. 2020) (p. 2). The impact envisaged in the end-of-project time frame (4 years), set out in project logic with expected activities and outputs, was: "Traditional Owners in the Fitzroy River Catchment effectively use knowledge to have influence over land, water, development and conservation options to meet their aspirations". These aspirations were subsequently documented in their Fitzroy River Declaration (Traditional Owners of the Fitzroy River, 2016) (Box 1). The Declaration responds in part to the Western Australian state government's initiative to distribute water from the Fitzroy River, through a Water Allocation Plan to be finalised by 2021 or soon after (GoWA 2020).

Research interactions began in November 2015 at a meeting in Fitzroy Crossing that identified the need to ensure greater access to by Traditional Owner groups to each other's knowledge about the catchment, and to scientific knowledge (Hill et al. 2016). The research team included seven scientists (from Australia's national science agency CSIRO, James Cook University, Griffith University and the University of Western Australia), and sixty-three participants from the ten Traditional Owner groups in the Fitzroy catchment. A Regional Research Coordinator, employed by the Kimberley Land Council (KLC), a non-Indigenous person selected together with the KLC and Traditional Owner groups, provided ongoing liaison, logistical cross-cultural support, founded in her deep experience and understanding of the region's history and cultural protocols, extensive social networks, having previously lived there for almost 20 years.

Cooperative research agreements between the research organisations, the KLC and the Traditional Owner groups and organisations, colloquially known as PBCs, (Table 1) supported the project. Negotiation of the agreements, which provided guidance on the roles of all parties and processes to ensure access to research outputs and protect Indigenous intellectual and cultural property, was supported by the KLC's Research Ethics and Access Committee, the National Environmental Science Program's Northern Australia Environmental Resources (NAER) Hub, and took more than two years to finalise. Ethical clearance was received from the CSIRO Social and Interdisciplinary Science Human Ethics Committee.

Each iteration of the action co-research cycles through workshops and/or presentations (summarised in Fig. 3 and Supplementary Table S1) involved an ongoing process of reflection and learning.

Participants were selected through different purposive samples in discussions between the Traditional Owner groups, the research team, the Regional Coordinator and relevant Indigenous organisations. Data were collected through video, audio and photographic recording and note-taking by the scientists and Traditional Owner participants at four workshops: the "Project commencement workshop" in July 2017; the "Workshop to develop 3D map influence maps" in December 2018; the "Workshop to use the 3D map, interactive projector and influence mapping" in July 2018; and the "Final workshop to develop building blocks and evaluate participatory mapping" in December 2019 (Fig. 3, Supplementary Table S1). Consent was also sought and provided to release data from "Presentation to senior public servants in Canberra" in February 2019. Collaboration with a scenario planning project running concurrently in the Fitzroy River catchment (Kim et al. 2021 in review) enabled the research team to engage in futures thinking at a "Scenario planning workshop" in September 2019, which led to the inclusion in the final project workshop of more futuresthinking approaches - approaches that enable participants to use creativity and cultural beliefs to imagine pathways to a desired future different to today (Pereira et al. 2018).

Written evaluations forms, seeking both Likert-scale (Likert 1932) quantitative responses to questions and written comments, were completed by workshop participants at the end of each of the first three data-collecting workshops, and a similar evaluation reflecting on the whole project completed at the December 2019 workshop. At this workshop, Traditional Owners identified the key messages that they wanted to communicate to governments, communities, and the scientific 


\section{Fitzroy River Declaration}

Traditional Owners of the Kimberley region of Western Australia are concerned by the extensive development proposals facing the Fitzroy River and its catchment and the potential for cumulative impacts on its unique cultural and environmental values.

The unique cultural and environmental values of the Fitzroy River and its catchment are of national and international significance. The Fitzroy River is a living ancestral being and has a right to life. It must be protected for current and future generations, and managed jointly by the Traditional Owners of the river.

Traditional Owners of the Fitzroy catchment agree to work together to:

1. Action a process for joint $\mathrm{PBC}^{1}$ decision making on activities in the Fitzroy catchment;

2. Reach a joint position on fracking in the Fitzroy catchment;

3. Create a buffer zone for no mining, oil, gas, irrigation and dams in the Fitzroy catchment;

4. Develop and agree a Management Plan for the entire Fitzroy Catchment, based on traditional and environmental values;

5. Develop a Fitzroy River Management Body for the Fitzroy Catchment, founded on cultural governance;

6. Complement these with a joint Indigenous Protected Area over the Fitzroy River;

7. Engage with shire and state government to communicate concerns and ensure they follow the agreed joint process;

8. Investigate legal options to support the above, including:

1) Strengthen protections under the EPBC Act ${ }^{2}$ National Heritage Listing;

2) Strengthen protections under the Aboriginal Heritage Act; and

3) Legislation to protect the Fitzroy catchment and its unique cultural and natural values.

Box 1 Fitzroy River Declaration (Traditional Owners of the Fitzroy River 2016). ${ }^{1} \mathrm{PBC}$ is a Prescribed Body Corporate, the local colloquial term for Aboriginal organisations established at Native Title RepresentativeBodies, ${ }^{2}$ Environment Protection and Biodiversity Conservation (EPBC)

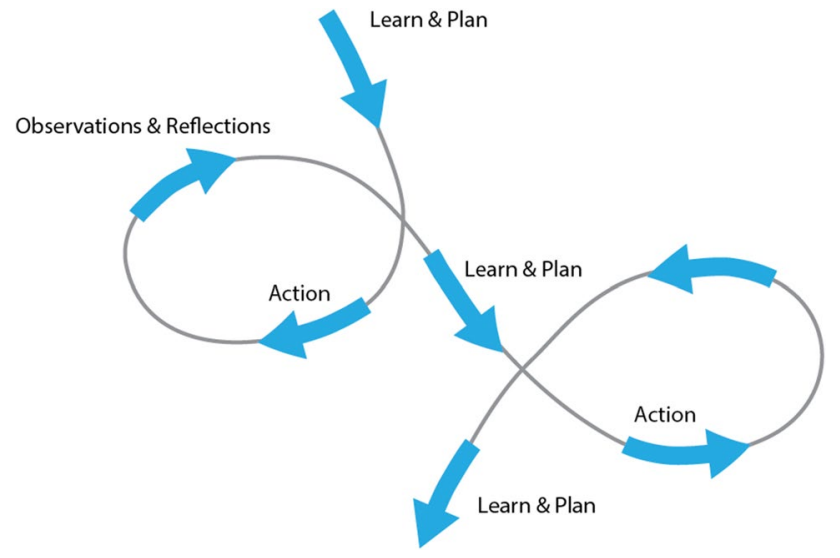

Fig. 2 Action co-research cycles

literature from the project. One scientific publication from the project was agreed, with the key message of "learning together". Traditional Owners requested that the scientists draft the paper (this paper) using an appropriate analytical framework, that they become co-authors, and that the procedures under the cooperative research agreements be followed for approval of the publication through their Traditional Owner groups and organisations (Table 1). These procedures required that Traditional Owner experts identified by these groups agreed that the analytical framework, the results, conclusions and the paper as a whole were appropriate prior to its approval for publication.

The first visual/tactile spatial platform, the 3D map, was largely constructed over a 3 day period at a workshop in December 2017 using the method presented in Fig. 4 and in an online video (Traditional Owners and Researchers 2018). An interactive table-top projector connected to a computer, with a pen that allowed touch-tracking on the table-top, was used to display and overlay spatial data. Data provided are found in Supplementary Table S2. 
ACTIVITY

DATE

2015

Research priorities

workshop with Traditional

Owners

NAER Hub research
planning workshop

Project commencement workshop: co-design, peer-to-peer learning

Workshop to develop 3D map \& influence maps

Presentation of 3D map and video at Native Title Conference
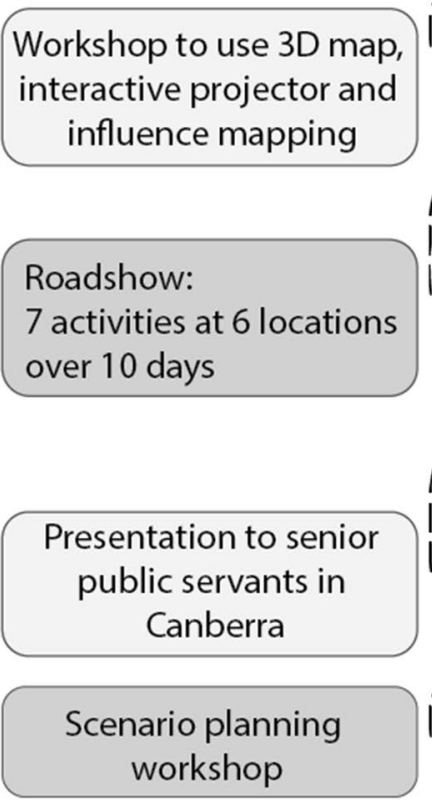

Final workshop to develop building blocks and evaluate participatory mapping

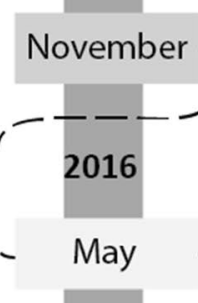

One to Indigenous \& science knowledge

Traditional Owners support idea of 3D catchment model

Traditional Owners navigated cultural protocols to agree on joint activities

Traditional Owners excited by new insights into power, cultural and spatial relationships

Traditional Owners communicated their excitement from using these platforms.

Platforms used to develop strategies to achieve Traditional Owner cultural governance and management planning aspirations
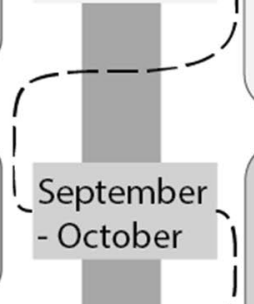

Traditional Owner adults and children engaged in knowledge sharing with enthusiasm and identified improvements to the platforms

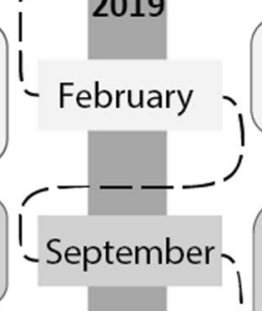

\section{9}

\section{hel}

Traditional Owners identified focus on building blocks as helpful to envisaging pathways to desired future

High level support for visual/tactile platforms

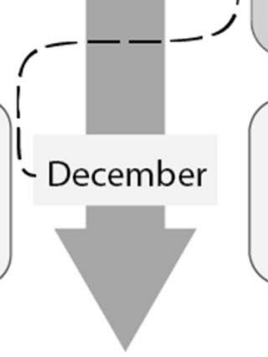

Traditional Owners identified learning together and with the river as critical outcomes from the project
OBSERVATIONS

PLANNING

Development of knowledge co-production proposal

Researchers plan co-design workshop

Worked with schools to plan building 3D map with Traditional Owner children

Developed opportunity for knowledge sharing using using new platforms

Continued to explore use of these platforms in other contexts.

Co-organised roadshow in 3 towns in the catchment with Traditional Owners

Development of educational materials and support for Traditional Owners to use the platforms in the future

Continuing to explore the use of these platforms in other contexts

Development of building blocks as a focus for final workshop
Handing over the visual/tactile platforms with training for long-term use in the catchment by

Fig. 3 Timeline of project activities (NAER stands for Northern Australia Environmental Resources) 


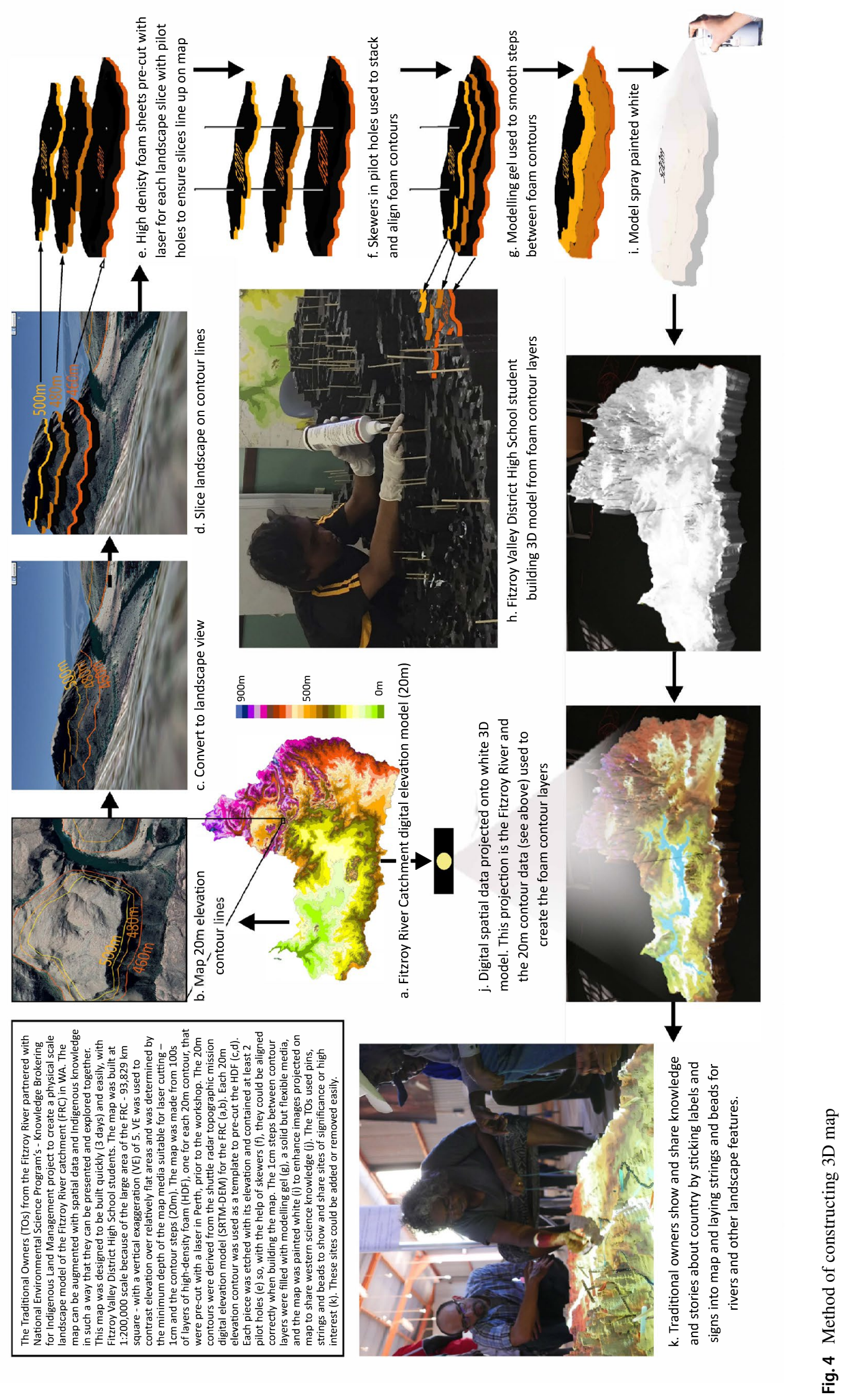


The participatory influence mapping activity used a mixture of Net-Map, a commercially available product, together with a selection of buttons, pens and butcher's paper (Schiffer and Hauck 2010; Hauck et al. 2015). In the December 2017 workshop, Traditional Owners were first asked to selforganise into groups and then work together, guided by a facilitator, to identify the organisations (including organised groups) that can affect the success of the cultural governance and management planning aspirations set out in the Fitzroy Declaration (Box 1). These goals were prioritised through discussions. They then identified, using self-determined categories, the types of connections between the organisations (e.g. money, policy, advice). Next, the extent of power of each organisation was assessed using an influence stacking exercise, again based on self-determined understandings of power. Participants piled up buttons to represent the level of power of each organisation, with higher piles corresponded to higher power, discussing their reasons for allocations of power. They identified whether organisations were supportive of or opposed to the cultural governance and management planning goals. The resulting data were de-identified, analysed for common themes, and to summarise the organisations identified, their connections, their levels of influence and support or opposition to the Traditional Owner's goals. Results of these analyses were presented back to Traditional Owners during the July 2018 workshop and used to stimulate discussions about how to leverage these connections to generate more power for their goals.

All the data, including video, audio, photographic records and the written notes and evaluations, was subject to thematic analysis for this paper, and parts of these data were also used to produce videos, reports and fact sheets (see project web-site https://www.nespnorthern.edu.au/projects/nesp/knowledgebrokering-indigenous-land-management/). Validity of the research was based first on the deep engagement with Traditional Owners to address the community-driven issues and the peer-to-peer learning that was embedded in the action learning cycles. The step-wise process of identifying and addressing a shared key issue amongst the Traditional Owners, the collective review and reflection of the results from each meeting to progress dialogue, through each cycle, established the relational accountability of the research in accordance with Indigenous-driven research methods and our action coresearch approach (Smith 1999; Louis 2007; Wilson 2008).

\section{Framework for analysis}

The framework for analysis of the project was selected by the scientists in the team, and reviewed by Traditional Owner experts selected by the groups' organisations. Literature review of methods for interrogating impact from knowledge co-production identified a recent framework (Schneider et al. 2019) that built on previous fragmented approaches and synthesised a method capable of addressing the complexity of real-world projects. A modified version of this framework was adopted (Table 1). Knowledge promotion, social learning, and enhancing influence provided our underlying mechanisms for impact, each associated with a theory about how change occurs (first columns of Table 2), to deliver the envisaged impact and desired sustainability transformation established by the Indigenous-majority steering committee (last column of Table 2).

Knowledge promotion is based on the theory that change is triggered by improved access to knowledge. The salience/ relevance, credibility, legitimacy, applicability, accessibility/actionability, comprehensiveness/holism and timing of knowledge have been demonstrated to affect its accessibility for decision-making (Cash et al. 2003; Dunn and Laing 2017). Useful knowledge in Indigenous societies is collectively held, owned and managed and demonstrates capabilities for innovation and adaptation, and for generating excitement and enthusiasm in the group (Guillemette et al. 2017; Wheeler and Root-Bernstein 2020). However improved access to knowledge depends on social characteristics of the users as much as the knowledge characteristics (Jasanoff 2004). For Traditional Owners seeking to transform the colonial context and re-assert their rights to lead, competences of personal and group empowerment to effect change are critical (Zurba et al. 2018; Poelina et al. 2019). These competencies are characterised by: acquisition of personal and embodied knowledge; self-transformation towards a more complex self; the ability to become change agents; and the capacity and confidence to help others better understand the context they are working in (Raymond et al. 2018; Schneider et al. 2019). Our team of scientists and Traditional Owners developed and used the two visual/tactile spatial platforms to support knowledge promotion and sought to deliver envisaged immediate outcomes of improved characteristics of the knowledge (i.e. relevant, credible, holistic, legitimate, innovative, adaptable, actionable, timely, applicable, exciting/stimulating) and improved experiences of knowledge users (middle two columns of Table 2).

Our second underlying mechanism for impact, social learning i.e. social interactions between actors within social networks that lead to changes in understanding going beyond the individual, is based on the theory that change is an emergent property of coordinated actions (Reed et al. 2010; Schneider et al. 2019). Social learning among Indigenous and non-Indigenous people has the potential to foster qualities of respect, trust, personal relationships, mutual benefits, and a commitment to ongoing learning and knowledge evolution that underpin collective action (Milgin et al.; Muro and Jeffrey 2008; Lebel et al. 2010; Leys and Vanclay 2011; Woodward and McTaggart 2016; Roux et al. 2017; Chapman and Schott 2020). Among Indigenous peoples, peer-to-peer exchanges produce superior outcomes for social learning (Tschirhart 


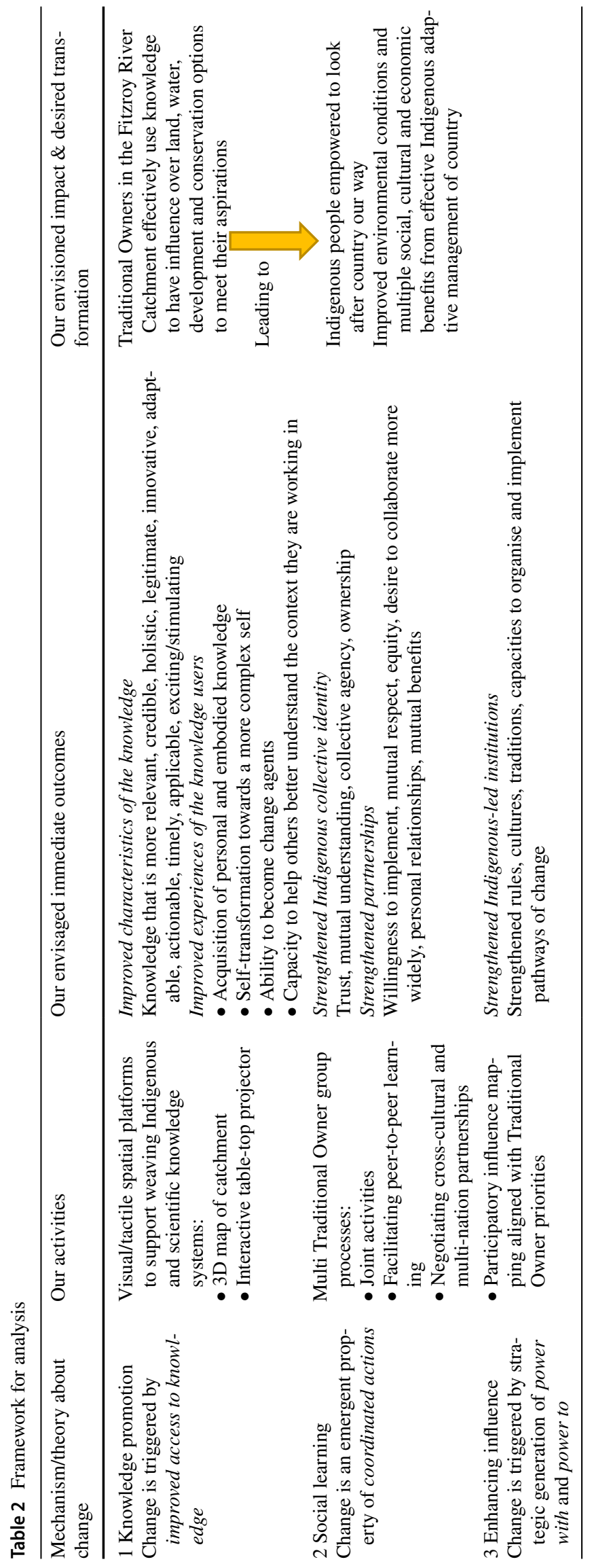




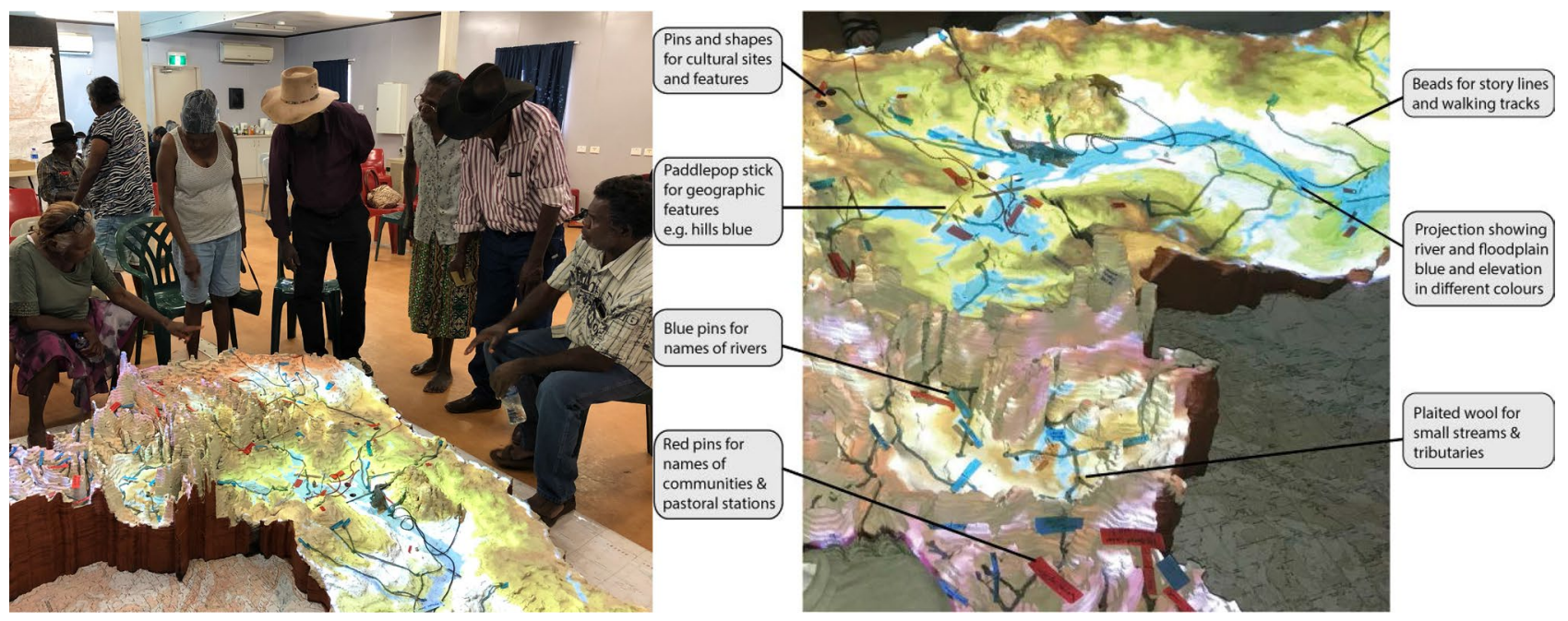

Fig. 5 Using the 3D map for Indigenous and scientific knowledge-sharing

et al. 2016; Ford et al. 2020). Multiple Traditional Owner groups came together for joint activities in workshops, which facilitated peer-to-peer learning and negotiated equity in cross-cultural partnerships to support social learning and deliver envisaged immediate outcomes of strengthened Indigenous collective identity (characterised by trust, mutual understanding, collective agency and ownership) and strengthened partnerships (characterised by willingness to implement, equity, mutual respect, desire to collaborate more widely, personal relationships, and mutual benefits) (Table 2).

Our third mechanism, enhancing influence, is based on the theory that change is triggered by strategic generation of power (Hill et al. 2015; Turnhout et al. 2020). Power arises in manifold ways-for example from control of financial resources or from positions in a social structures (Fritz and Meinherz 2020). Here the focus is on power with and power to that arises through social relations, the ability of agents to influence the choices and actions of others, to constrain or enable, an outcome (Pansardi 2012). The terms power and influence are used interchangeably throughout to describe this aspect of power from social relations. Social institutions such as culture, pathways of change, traditions-i.e. formal and informal rules, and norms - can mobilise power and influence (Avelino and Rotmans 2011). For Traditional Owners in the Fitzroy catchment, recognition of native title necessitates the establishment of Prescribed Bodies Corporate (PBCs) who operate under a governance system which offers some control over land but limited control over water and mineral resources. Indigenous self-determined institutions are critical to generate influence in this context, where both civil society and corporate actors exercise influence (Lim and Poelina 2017). Participatory influence mapping, aligned with Traditional Owner priorities, was undertaken for enhancing influence to deliver an envisaged immediate outcome of strengthened Indigenous-led institutions (characterised by strengthened rules, culture, traditions and capacity to organise pathways of change).

\section{Results from stage one of the research: knowledge co-production activities}

\section{Activities supporting the first mechanism for impact: Knowledge promotion}

The key activities to support knowledge promotion were development and use of two visual/tactile spatial platforms: a 3D catchment map, and an interactive table-top projector.

\section{Visual/tactile spatial platforms: 3D map and interactive table-top projector}

The 3D catchment map showed the shape of the land surface, with a vertically exaggerated scale, and major streams in the catchment. Digital spatial information was displayed using an overhead projector, including elevation, drainage, fire and flood history, native title status, pastoral and mining interests, protected areas, and hotspot maps depicting important areas for biodiversity conservation derived from desktop spatial analyses. The model's surface was soft to allow Traditional Owners to use pins and beads to show cultural knowledge including walking tracks, historical paths, dreaming tracks, songlines and stories (Fig. 5).

Many more spatial data layers were shown on a table-top using the interactive projector, which allowed Traditional Owners to choose which data to show, to overlay different data layers and also to change scales, zooming in to 


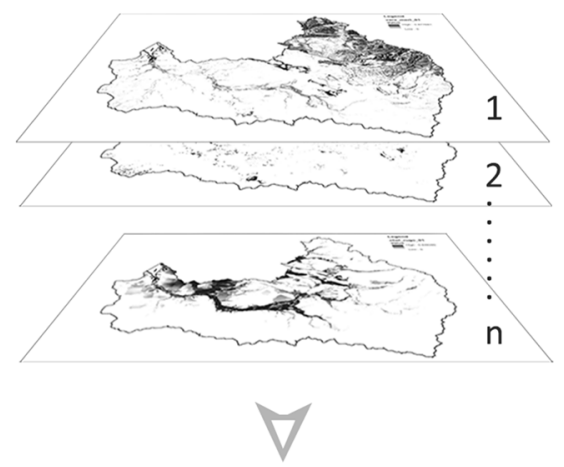

Interactive projector used to map the important places in the Fitzroy River Catchment based on the denisty of important species. Probability maps for plant and animals were projected onto the table top. Interactive mapping allowed participants to move map around, zoom into areas for a closer look, and add important features such as the river. to discuss the importance of each local plant and animal. Traditional Owners used this method to determine which plants and animals are important environment.

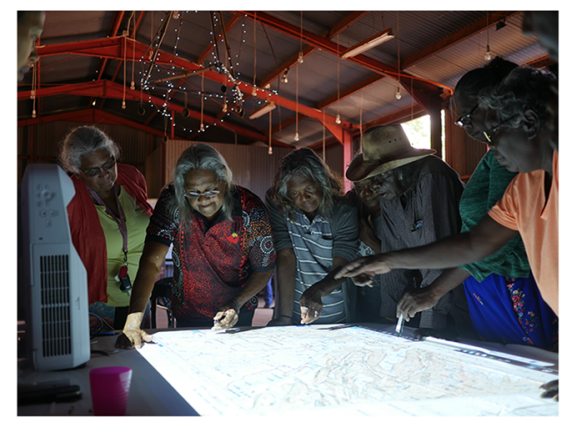
recorded sightings and environmental factors that determine the most likely habitat (e.g. rain and temperature). Probability map are grids and each cell in the grid has a value ranging from 0 , no likelihood of occurrance, to 1 , most likelihood of occurrance. They indicate where species are most (dark tones) or least (light tones) likely to be found in the

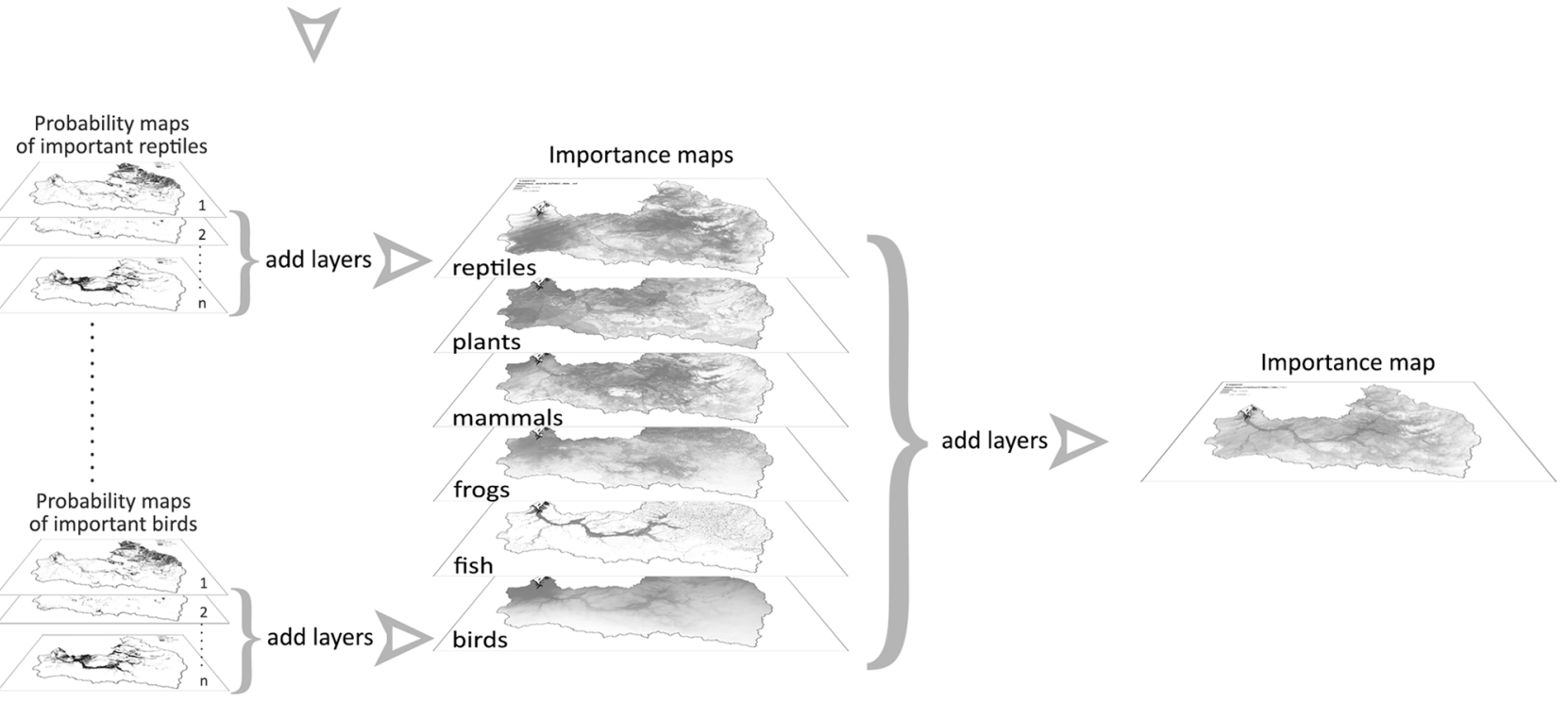

Sets of important plants and animals were grouped together based on kingdom (plants) and class (reptiles, birds, mammals). Each set was combined by adding together the probability of finding the species. These maps are grids, and spatially referenced, so the grid cells align when maps are layered one on top of another. For example, at one location, the probability of finding an important lizard species is 0.1 and the probability of finding a crocodile there is 0.5. These species are important, and when combined the Importance Value at that location is $0.1+0.5=0.6$. The higher this value to more important species are at that location. NB Importance Values are not probabilities and can be greater than 1.

Fig. 6 Using the interactive projector for mapping a buffer along the river 
a fine-scale to examine areas of interest. This capability was used by Traditional Owners to select and overlay data to inform the creation of a buffer zone for excluding mining, oil, gas irrigation and dams in the Fitzroy catchment (one of the goals of Fitzroy River Declaration) (Fig. 6).

\section{Activities supporting the second mechanism for impact: Social learning}

\section{Multi-traditional Owner group workshops and activities}

Finding ways to share knowledge at the workshops stimulated much learning about cultural protocols. All Traditional Owner Groups follow the protocol that one should only speak for one's own Country, and ideally be on their own Country to talk about it. Two options were considered that allowed for adherence to this protocol. The first option was for each group to take responsibility for building only that part of the 3D map which was their traditional Country, together with community members on that Country, and later bringing each part together at a central venue to assemble it. The second option was for delegates from each group to come together into a common venue to build only that part of the map which was their traditional Country and then assemble the whole. However, there were insufficient project resources in time and finances to support the first, and no venue sufficiently large to support the second. One of the workshop participants adopted a more pragmatic position:

Google Earth comes in and maps all of our Country without even asking us and we all use that map. Surely we can all get together and make our own map (Traditional Owner Workshop Participant, July 2017).

Discussions highlighted that the 3D map could facilitate a different cultural protocol: the requirement for intergenerational knowledge transfer. The schools and Traditional Owner children attending them were identified as vital partners in this project. Building of the 3D map occurred between the adults and children in December 2017, and proved successful:

Good that kids got involved in the model, that was the best part (Traditional Owner Workshop Participant, December 2017).

The 3D model facilitated intergenerational knowledge transfer on the "Road Show" (September-October 2018, see Fig. 3), bringing together adults and children from several of the ten Traditional Owner groups, in diverse combinations, at Fitzroy Valley and Derby State High Schools, and at the Kimberley Land Council Annual General Meeting, which attracted more than 500 Traditional Owners (Table S1).

Further navigation of and learning about cultural protocols was required to discuss culture and cultural values at the workshop in July 2018. The workshop participants decided to break into separate men's groups and women's groups, as significant cultural knowledge can only be transmitted through gender-specific groups. No cultural knowledge recordings were kept, as participants identified that the setting was not appropriate-other people (e.g. senior knowledge-holders) were required to be present, and the PBCs, rather than research organisations, should record the data.

\section{Facilitating peer-to-peer learning}

Social learning was also facilitated through the focus on Indigenous peer-to-peer learning. In July 2017, the project brought a Traditional Owner from Mandingalbay Yidinji, a group from eastern Australia, to present their 3D map and explain its use, stimulating substantial discussions. Peer-to peer learning was also supported by bringing together groups from the top of the catchment with those near the river mouth:

Strong voices alone is not as strong as people from the river mouth to the hill country standing together (Workshop Summary, July 2018)

It's good to be here sharing and talking about the river... all language groups working together as a team about the river (Traditional Owner Workshop Participant, November 2019).

Stories told around the 3D map overcame the logistical barriers to getting out on country for knowledge exchanges. The 3D map was showcased by Traditional Owners and researchers to more than 1000 participants at the National Native Title Conference in Broome and to senior public servants in Canberra in February 2019. Traditional Owners highlighted the learning outcomes:

This NESP project has come on board with us to help us in different ways - both way learning ... I hope it keeps going" (Traditional Owner Presenter, Canberra February 2019).

Public servants reacted positively to the 3D map as a tool for communicating, visualising and learning about different knowledges:

It's such an engaging way to show country, to show the complexity, to show systems, to show so much. It's so powerful (Senior Staff, Department of Prime Minister and Cabinet, February 2019).

\section{Negotiating equity in cross-cultural and multi-nation partnerships}

Power asymmetries characterise the relationships between Indigenous nations and settler societies, and so the project 


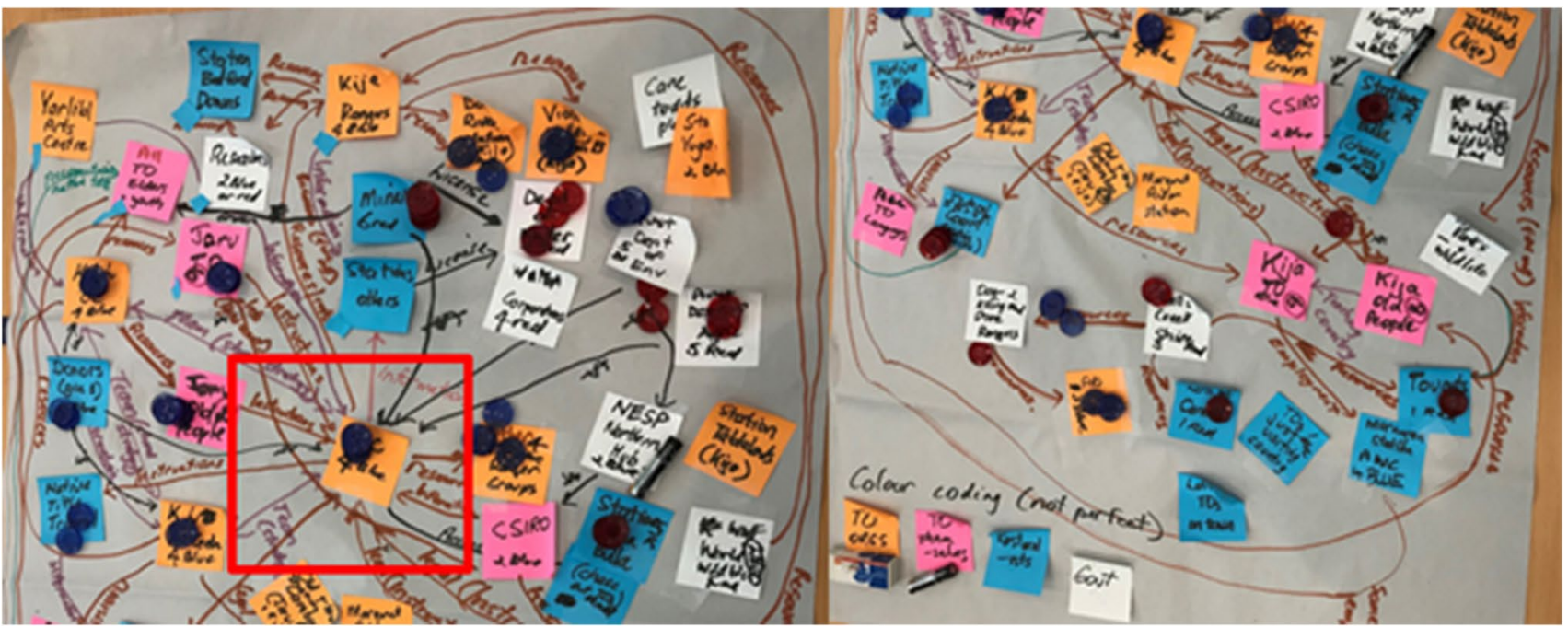

Fig. 7 Social network mapped by one of the groups, December 2017

used several methods to shift and equalize the power. First, recognition of equity between Indigenous and scientific knowledge systems was a key principle in the co-designed visual/tactile platforms and the overall project approach. Second, researchers took on the role of food preparation at the workshops, serving breakfast and dinner, clearly placing themselves in a subsidiary role, which allowed the Traditional Owners to give instructions about how to follow cultural protocols, for example stressing that senior people must not be kept waiting for food, and must be served first. These meal settings allowed for relationships building:

Loved the food, talking to each other, working (Traditional Owner Workshop Participant, December 2017).

Third, an interpreter was employed to support all workshops. The interpreter provided translations from English into Kimberley Kriol, the common language across the nine language groups in the region, and guided choice of English words for the presentations-most of the participants have some English literacy. The interpreter's role was critical for the informed consent - she carefully explained the consent being sought, and guided participants through an English language form. The interpreter used body language to convey difficult concepts and guided researchers to use visual communication:

Talking to the picture to communicate with Aboriginal people (Traditional Owner and Interpreter, December 2017).

The interpreter also set up role plays between the Traditional Owner participants to act out challenging concepts, such as "negotiation". Finally, relationships were supported through staying together in accommodation with shared cooking facilities, having common social events, including playing music together, Traditional Owners showing researchers how to make damper, and informal conversations.

\section{Activities supporting the third mechanism for impact: Enhancing influence}

\section{Participatory influence mapping aligned with Traditional Owner priorities}

The participatory influence mapping focused on the cultural governance and management planning aspirations set in the Fitzroy Declaration, identified as priorities from workshop discussions (Box 1). This mapping activity first involved twenty-one Traditional Owners who self-allocated into four groups, dividing according to family, territorial, kinship and gender protocols. Many different organisations were identified in the four networks (one drawn by each group), and these were loosely colour-coded into categories, for example as Traditional Owner (TO) organisations; TO informal groups; pastoral; and government (Fig. 7). Six types of connecting relationships were identified among the organisations. These were provision of: information, training, funds, resources, advice, and rules-policy. Each of the four groups identified some organisations with many connections and others with few but placed different organisations centrally in their networks.

Exploring differences among the various Traditional Owner groups in terms of current influence allowed expression of collective solidarity and identity:

When you mob [a claimant group that has not yet finalised its native title] get your PBC ... Don't think we're putting you to one side. You get all the informa- 


\section{Provides Information}

- Ambooriny Buru Charitable Foundation (KRED)

- Anthropologists

- Archives/History

- Commonwealth Scientific and Industrial Research Organisation (CSIRO)

- Indigenous Community People

- Parks and Wildlife Service

- Respected Cultural Elders

- Rangers

- Scientists

- Universities

\section{Provides Rules}

- Department of Planning, Lands and Heritage (State)

- Department of Water (State)

- Mining Companies

- Pastoral Land

- Pastoral Stations

- Respected Cultural Elders

- Scientists

- Shires

\section{Provides Training}

- North Regional TAFE

- The North Australian Indigenous Land and Sea management Alliance Ltd (NAILSMA)

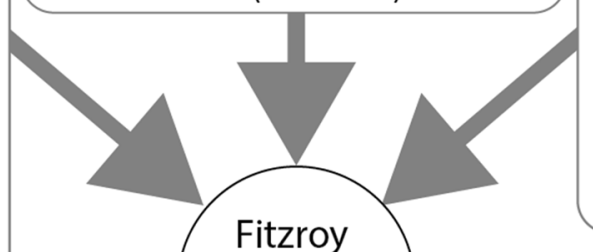

Fitzroy River

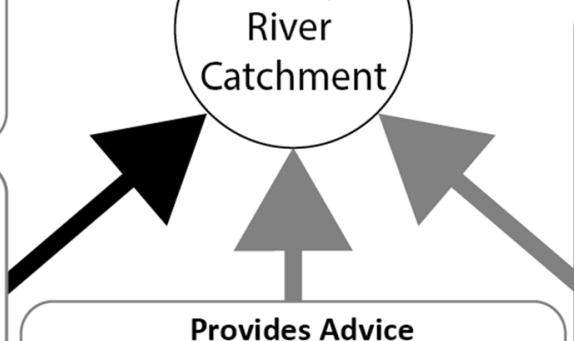

Provides Advice

- Ambooriny Buru Charitable Foundation (KRED)

- Department of Agriculture and Water Resources (National)

- Kimberley Aboriginal Law and Culture Centre (KALACC)

\section{Provides Funding}

- Claimant Groups

- Department of Environment

- Kimberley Language Resource Centre (KLRC)

\section{- Mining Companies}

- Northern Environmental Science Programme (NESP) Northern Hub

- Researchers

- Universities

\section{Provides Resources}

- Aarnja Aboriginal Regional Body (AARNJA)

- Commonwealth Scientific and Industrial Research Organisation (CSIRO)

- Dog Killing and Shire Rangers

- Halls Creek Shire

- Kija Rangers

- Kimberley Development Commission (KDC)

- Universities

- Department of Petroleum and Minerals (State)

Fig. 8 Summary of the organisations using different types of connection. Plain font identifies those perceived to support the Traditional Owners' aspirations for cultural governance and management planning; bold, italic font identifies those perceived to oppose these goals

tion from us what we say in here. When we have meeting in Fitzroy, come along. You'll learn more (Traditional Owner Workshop Participant, July 2018).

The discussion of power through influence mapping was a new way of thinking and talking about relationships and types of influence agencies and groups have across the catchment:

Influence mapping, [it gave me] more understanding of who has got the power, where they get it from (Traditional Owner Workshop Participant, July 2018).

Power was perceived to derive from both nation-state laws and customary law, with Traditional Owners identifying their own senior leaders as holding substantial power:

They've [Elders] got their own power. They've got their own law and they're strong and they stick to their own rule... they're strict in their rules (Traditional Owner Workshop Participant, December 2017).

Power was described as having influence from afar or near, as enduring through spiritual presence and ancestors, or holding temporary influence. Customary law is a strong source of power and one that is perceived as embedded in the Fitzroy River Declaration (Box 1). Rules, policy and law from the nation-state were highlighted as an important source of influence that Traditional Owners must become adept at using:

We have to understand their rules as well. When something goes wrong, we can use the government rules to say, 'Hey'... We got to know what the rules are. We can use the rules for managing water (Traditional Owner Workshop Participant, July 2018).

Participants also spoke about establishing influence through Indigenous-led institutions that operate within and use the nation-state representative system:

Since we've had our corporation, we have that influence, everyone is starting to talk to us. As an example, the education department wanted to put a house out at [community name] ... they came direct to us the PBC. These are the sort of influence we are having. That is how government is seeing us (Traditional Owner Workshop Participant, July 2018). 
Nevertheless, the summary (Fig. 8) revealed that most of the organisations that established or set rules (under various types of nation-state legislation) were perceived to oppose Traditional Owners' aspirations for cultural governance and management planning of the Fitzroy catchment.

At the final workshop in December 2019, participants focused on six 'building blocks' as pathways towards futures that achieved these cultural governance and management planning aspirations: (i) strengthening rules, laws and stories; (ii) strengthening Traditional Owner relationships with one another and (iii) with others (non-Traditional Owners); (iv) increasing knowledge of new and (v) established economies to identify opportunities for economic development; and (vi) creating a buffer zone for excluding development around the river. Strategies to develop, strengthen, and overcome to establishing these building blocks were discussed at the December 2019 workshop.

\section{Results from stage two of the research: analysis of progress towards envisaged immediate outcomes and impacts}

This section presents the analysis of the envisaged immediate outcomes, and the overall impact and desired transformation, using the framework presented in Table 1. Results from the analysis are summarised in Tables 2 and 3.

\section{Envisaged immediate outcomes from the first mechanism for impact: Knowledge promotion}

The first mechanism, knowledge promotion, is based on the theory that change is triggered by improved access to knowledge. This mechanism is envisaged to produce improved characteristics of the knowledge, and improved experiences for knowledge users, with key characteristics as set out in Tables 2 and repeated in Table 3.

\section{Improved characteristics of the knowledge}

The main ways the characteristics of knowledge were improved was through becoming more relevant, holistic, innovative, timely, applicable and exciting/stimulating. These characteristics were supported through the visual/ tactile spatial knowledge platforms, and by discussion of new economies as a building block for realising Traditional Owner aspirations.

The 3D model improved the holism among Indigenous and scientific knowledge systems:
Learning about the river from scientists, I'm learning from Elders, learning from other groups, they've given me a lot of insight about my Country (Traditional Owner Workshop Participant, Nov 2019).

Senior public servants and Traditional Owners were excited and stimulated by this holistic source of information for the whole catchment. The innovative characteristics of the 3D map, in terms of the feel of the surface, and the bright colours moving across it with the projected data, also excited the children (Table S1). Participants identified new ideas as a strong result of the project, both in their comments and in the formal project evaluation (Fig. 9):

What I've learnt today, you know with new ideas ... all of us, can use to start a new program. (Traditional

Owner Workshop Participant, November 2019).

The relevance and timeliness of the knowledge was evident in the Road Show-Traditional Owners used the 3D map to discuss some of the current proposed conservation and development initiatives. Timeliness was highlighted in workshop discussions:

The big message is we got two years to get this story right because government has got a plan about how it wants to cut up that water (Traditional Owner Workshop Participant, July 2018).

Traditional Owners found the information from interactive projector applicable because they could 'run it themselves': choose which layers to add, remove and overlay, and zoom to see data at high resolution.

However, there were challenges for these platforms to provide credible, adaptable and actionable knowledge characteristics. The project lacked the appropriate settings for recording cultural data due to concerns regarding the absence of key knowledge-holders, ownership and control of any data recorded, challenging the credibility of the knowledge:

Some connections were difficult because there are family connections but we don't know if they can speak for that Country ... some important people are missing (Workshop Participants, July 2018).

While Traditional Owners engaged in sharing cultural information using the mapping tools, they decided not to record the outcomes of this activity. The absence of any recordings therefore makes it difficult to action these knowledge resources.

The 3D map presented challenges in terms of the exaggerated vertical scale, and inaccuracies in some aspects of the scaling - some Traditional Owners with detailed knowledge of their Country were very confused by these aspects, which could not be changed. 


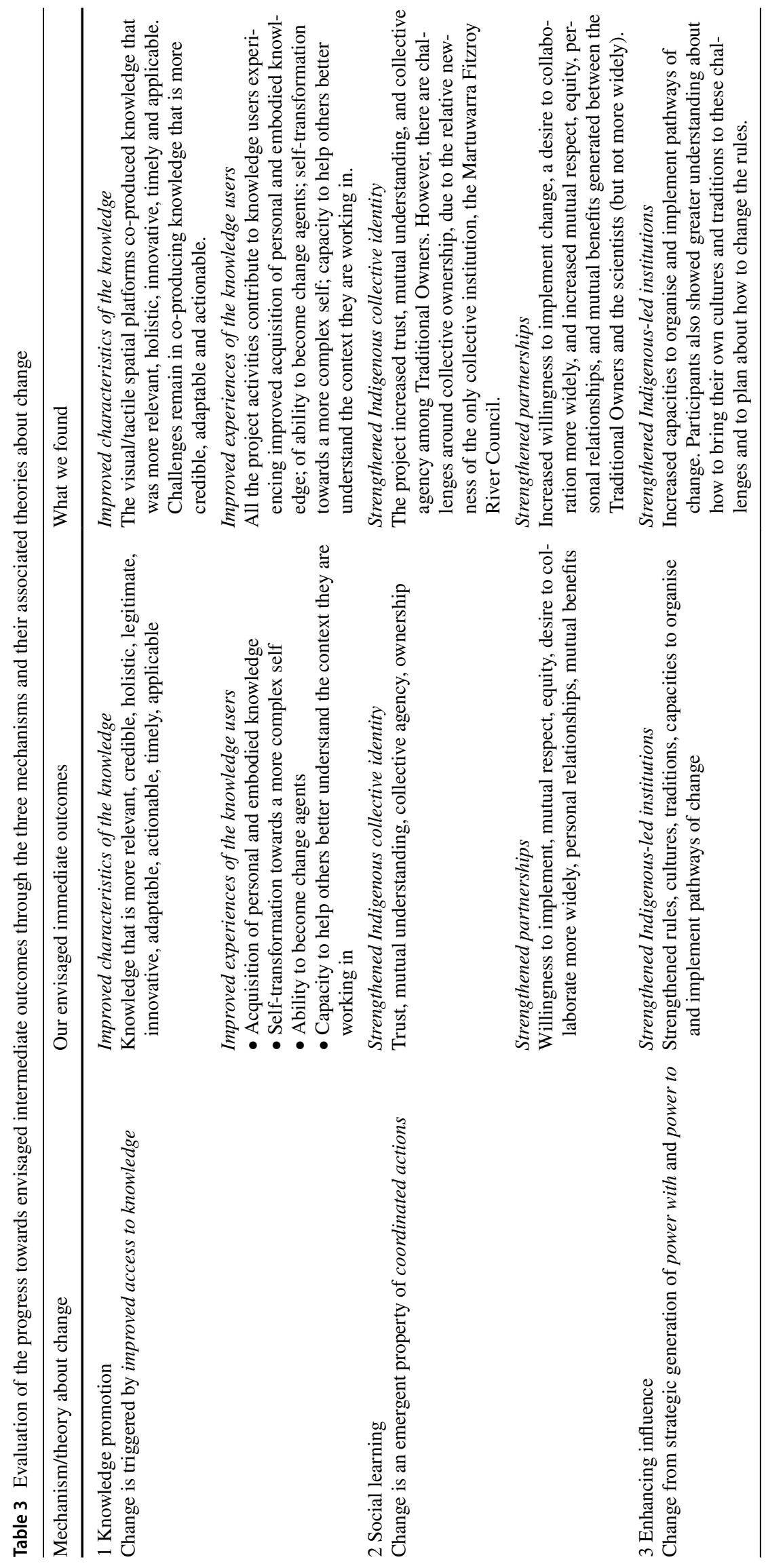


Evaluation Responses

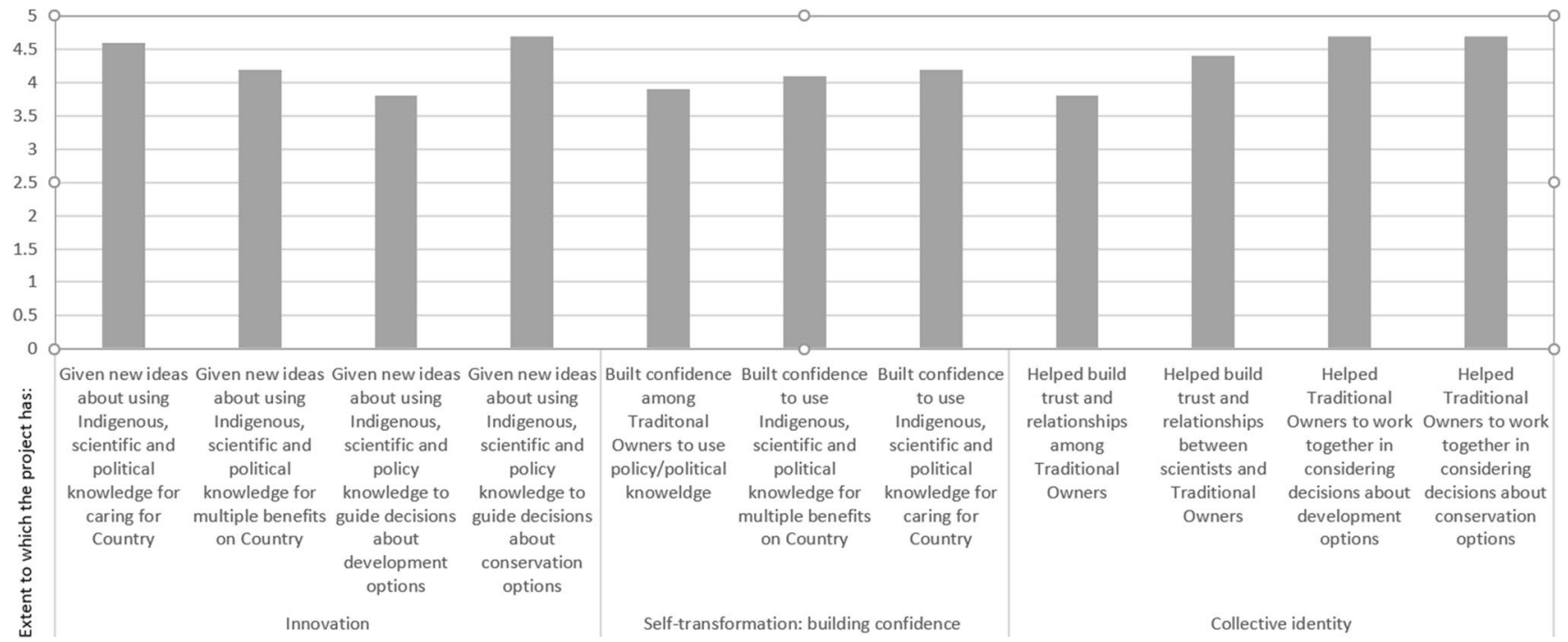

Fig.9 Quantitative results from the project evaluation by Traditional Owners at the final workshop $(N=17)$

\section{Improved experiences of the knowledge users}

The main ways the experiences of knowledge users were improved was through acquisition of personal and embodied knowledge, the ability to become change agents, self-transformation towards a more complex self with some evidence for improved capacity to help others understand the context. These characteristics were supported through all the project activities. Self-transformation in terms of confidence building was highly rated by the quantitative evaluation (Fig. 9) and was also reported qualitatively:

Ifeel a lot more confident because of the relationships and learning together with other Traditional Owners. In future meetings, if people who have been part of this project are together, then we will feel more confident in making decisions together (Workshop Participant,

November 2019).

Personal and embodied knowledge acquisition, self-transformation and the ability to become change agents in support Traditional Owners aspirations were also reported:

[The project] brought me back to life, it brought me back to understanding what is important - it brought me back to understanding why people like us put ourselves in front line and in jobs [i.e. speaking up for Traditional Owners aspirations for the Fitzroy catchment] like this. Because when you put yourself in a job like this, it's not just a job - it's larger than that, it's a lot more important (Traditional Owner Presenter, Feb 2019).
Evidence for perceptions of increased capacity to help others understand the context was identified through frequent offers of help by Traditional Owners to each other recorded in the discussions.

\section{Envisaged immediate outcomes from the second mechanism for impact: Social learning}

The second mechanism, social learning, is based on the theory that change is an emergent property of coordinated actions. This mechanism is envisaged to produce strengthened Indigenous collective identity, and strengthened partnerships, with key characteristics as set out in Tables 2 and repeated in Table 3.

\section{Strengthened Indigenous collective identity}

The main ways the Indigenous collective identity was strengthened was through increased levels of trust and collective agency (ability for Traditional Owners to work together), particularly reflected in the quantitative evaluation data (Fig. 9). Participants spoke of the project as highly effective for building trust and collective agency between Traditional Owner groups:

Helped build trust among TOs that joined this project (Traditional Owner Workshop Participant, November 2019).

More understanding [about] how to move forward together (Traditional Owner Workshop Participant, November 2019).

Mutual understanding among Traditional Owner groups was also clearly identified: 
Listening to stories from both sides of the river west, north, from the top to the mouth, how all the people are committed to the river (Traditional Owner Workshop Participant, July 2018).

However, there were challenges in establishing ownership-again partly because of the cultural protocols that place authority over Country with each of the ten groups, rather than with the collective. Many project participants perceived that each group needs one of the interactive projectors to display spatial data, with a trained operator and ability for ongoing updating of the data, to support Indigenous-led environmental planning. Nevertheless, the decision was made for the interactive projector and the compiled scientific spatial data to be handed to the Martuwarra Fitzroy River Council, along with delivery of appropriate training and resources to local staff, so it can be used to support collective environmental decision-making into the future.

The 3D map was perceived to be most useful in intergenerational knowledge transfer and education, and therefore most appropriately owned between the Fitzroy Valley District High School and the Derby District High school as central locations to enable access by Traditional Owner groups. The handover and training activities are scheduled for October 2021, depending on the absence of COVIDrelated travel restrictions.

\section{Strengthened partnerships}

The main ways partnerships were strengthened was through increased willingness to implement change, a desire to collaborate more widely, and increased mutual respect, equity, personal relationships, and mutual benefits generated among and between the Traditional Owners and the scientists.

Willingness to envisage and implement change was stimulated through the future scenario assessment workshop in September 2019. While defining pathways to a desired future proved challenging, identifying building blocksfoundations that could be laid now to build on as the future unrolled-was viewed as important. Two building blocks relevant to strengthened partnerships were identified as: working with rules and laws; and working with non-Traditional Owners (kartiya, the term used in Kimberley Kriol). Partnerships depend on strong cultural foundations:

Traditional Owners to be strong with their law, culture and language first before becoming strong in kartiya law/rules and kartiya education (Group Discussion Notes, November 2019).

Concerns were expressed that the Indigenous-led organisations were focused on kartiya governance systems and needed to change towards a stronger foundation in cultural governance. Participants recognised the need to partner with a wide array of others including local shires, state and federal government agencies, pastoralists, miners, agriculturalists, by building trust:

Need to build on the trust that's already there, find it, identify common ground, and build from there. Some TOs don't trust kartiya and vice versa; but it's not everyone. (Group Discussion Notes, November 2019).

The project had strengthened personal relationships, and trust:

We have learned to build trust and relationships between scientists and TOs (Traditional Owner Workshop Participant, November 2019).

The main mutual benefits from these strengthened relationships was from the learning together around the river:

Learning together ... different people, different Traditional Owner groups, about different things, each other and scientists, step by step, coming together around the river (Group Discussion Notes, November 2019).

Traditional Owner participants perceived that this was the most important result of the project and asked that the words "learning together" be the title of this collaborative paper from the project. Participants' aspirations to make influence maps together with non-Traditional Owners groups, as a way of building relationships, were not able to be supported through the project.

\section{Envisaged immediate outcomes from the third mechanism for impact: Enhancing influence}

The third mechanism, aligning participatory influence mapping with Traditional Owner priorities is based on the theory that change is triggered by strategic generation of power. This mechanism is envisaged to produce strengthened Indigenous-led institutions with key characteristics as set out in Tables 2 and repeated in Table 3.

\section{Strengthened Indigenous-led institutions}

The main ways the Indigenous-led institutions were strengthened in the project was through increased capacities to organise and implement pathways of change. Participants also showed greater understanding about how to bring their own cultures and traditions to these challenges, and to plan about how to change the rules.

Cultural governance has been strengthened as a result of native title:

Now that it [decision-making about country] has gone back to the PBC [organisation established to hold native title] there is more influence in our own cul- 
tural governance, the way we do things for Country on Country (Traditional Owner Workshop Participant, December 2017).

This strengthened cultural governance enabled participants to differentiate the old way of working, within nationstate systems, with a new Indigenous-led way:

We got to be brave because we are talking about new ways of doing business and sometimes our own mob might not like it. You got to have a go and put it out there... Sometimes we are looking out there for power but we also need to look inside our own systems, our own communities, our own PBCs and work out how can we make this better. Fair is the word (Traditional Owner Workshop Participant, July 2018).

The participants saw a strong need to strengthen the Indigenous-led organisations, and their institutions, operating at the catchment scale:

That change in terms of influence and power mapping is that the PBCs are saying let's stand together for the [Martuwarra Fitzroy River] Council. And the Council will have one mind and one voice. When we have different voice it can confuse the shift in power (Traditional Owner Workshop Participant, July 2018).

However, the analysis of the envisaged immediate outcome of strengthened Indigenous-led institutions from this mechanism did not identify strengthened rules, cultures and traditions per se. Rather, participants demonstrated an understanding of how cultures and traditions can be mobilised to change rules in ways that support Traditional Owners' aspirations.

\section{Envisaged overall impact and desired transformation}

Evidence is presented here from the qualitative and quantitative responses to the survey about the extent of achievement of the envisaged overall impact and desired transformation established by the Indigenous-majority steering committee for the project. This desired transformation is: "Indigenous people are empowered to look after Country our way; and Improved environmental conditions and multiple social, cultural and economic benefits come from effective Indigenous adaptive management of Country".

The establishment of the Martuwarra Fitzroy River Council, with its own set of rules, has increased the ability of Traditional Owners to use their knowledge to influence outcomes in ways that meet their aspirations. The MFRC is not a result of the project, it has arisen as a result of Traditional
Owners themselves, supported by the Kimberley Land Council and their PBCs, the organisations that represent their native title rights and interests. In addition, the Western Australian Government has provided funding support for the MFRC. Nevertheless, members of the MFRC participated in the project, and considerable discussion about strengthening the MFRC, occurred:

We want the Martuwarra Council to be its own legal entity. To stand on its own two feet to have its own resources, its own rules... It needs to get its own bucket of money so we can bring people to the table. (Traditional Owner Workshop Participant, July 2018).

Participants considered how other Indigenous-led organisations can continue to have influence, and engage in changing the rules to better meet Traditional Owner aspirations:

There's a brokerage role for the land council (in the short-term) ... The other thing the land council can do and is still doing is litigation. That's called strategic litigation... (Traditional Owner Workshop Participant, July 2018).

Traditional Owners are seeking coalitions across the catchment:

We are not sitting in the same mind set as 20 years ago. And that is why we have all the different mob here sitting down talking ... We are the people making the change ... if the Fitzroy Council is going to get up and get strong we got to have a coalition with Kimberley Aboriginal Law and Culture Centre, the Fitzroy Language Centre and the KLC (Traditional Owner Workshop Participant, July 2018).

The sustainability transformation sought through this project was envisaged as occurring in a 15-20-year time frame. Traditional Owners' interest in putting down building blocks - in terms of changing rules, strengthening their own alliances and partnerships with others-suggests transformative change is being initiated. In terms of environmental conditions, participants in the project often expressed their strong aspiration to protect the river, and all of their traditional territories:

Well I've never seen a TO who sat down, or stood up, or walked long, or slept on, the issue that, you know, one part of their Country is important and another part is not important .. every TO's Country is important. Every inch of it ... if you want to take the heart and soul out of man ... you take him away from his Country (Traditional Owner Workshop Participant, July 2018). 
The key message that workshop participants wanted to convey to governments from the project was about the health of Country and people:

Water is important, water in the grounds, on the surface, in pools - important to plants and animals. Country is important. TOs are passing on knowledge to look after Country. TOs at the mouth of the river are concerned about chemicals coming down the rivers, killing wildlife, bush tucker, and the health of the people at the bottom of the catchment. Chemicals are changing the environment. Country is changing, now there are cane toads and new weeds (Workshop Discussion Summary, November 2019).

Traditional Owners perceive that the Fitzroy River itself generates power and collective identity and they consistently emphasised the linkages to the river, that the river brought them together, and has an ongoing life and is the basis for cultural governance. Further, the key question for governments was about living and working together in ways that protect the river:

How can everyone live and work together in the Kimberley, everyone relies on the river for everything (Workshop Discussion Summary, November 2019).

Traditional Owners' interest in finding ways to work with others to improve the environmental conditions in the river again suggests that the envisaged overall impact of transformative change is being initiated.

\section{Discussion and conclusion}

What then are the conditions under which knowledge co-production can lead to improved Indigenous adaptive environmental planning and management among remote, land-attached Indigenous peoples? First, the findings from our knowledge co-production activities affirm the usefulness of visual/tactile spatial platforms, which are highly interactive boundary objects (Zurba et al. 2018). The 3D map proved effective in supporting inter-generational knowledge sharing and education; the interactive projector and spatial data assisted with environmental planning. The knowledge thus produced was found to be more relevant, holistic, innovative, timely, applicable and exciting. Knowledge-users who participated in the project experienced improved acquisition of personal and embodied knowledge; of ability to become change agents; self-transformation towards a more complex self; and capacity to help others better understand the context they are working in. The usefulness of visual tools for spatial data to support future thinking through scenario planningwas confirmed in this project, reinforcing the usefulness of similar approaches identified with First Nations in Canada (Natcher et al. 2021).
Second, the social learning led to strengthened Indigenous collective identity, with increased trust, mutual understanding, and collective agency among Traditional Owners. There were multiple layers of learning together, step by step, through multiple actions learning cycles. However, there are challenges around collective ownership and action, due to relatively newness of collective organisations, such as the Martuwarra Fitzroy River Council. The social learning also facilitated increased willingness to implement change, a desire to collaborate more widely, and increased mutual respect, equity, personal relationships, and mutual benefits between the Traditional Owners and the scientists (but not more widely). Learning together, and with the Fitzroy River, through the project was highlighted by Traditional Owner participants as the most important result.

Third, participatory influence mapping increased participants' capacities to organise and implement pathways of change. Participants also showed greater understanding about how to bring their own cultures and traditions to these challenges and to plan about how to change the rules.

The focus on cultural governance and management planning goals in the Fitzroy River Declaration, enabled the knowledge co-production activities to directly affect key drivers of Indigenous adaptive environmental planning and management, the Indigenous-led institutions. This appears a critical conditionknowledge co-production with Indigenous peoples leads to change where it is embedded in deliberations that are led by Indigenous institutions and addresses their priorities. In this case, the nation-state arrangements gave some support to local learning and decision-making reinforcing the recent finding that such support is a key requirement (Hill et al. 2020).

Remote Indigenous land-attached peoples encounter continuing dispossession and erasure of influence over their ancestral lands and waters through the administrative systems of government and the private/corporate ownership and control of property, land and water (Wolfe 2006). Traditional Owners here have drawn power from their identity-based relationships along the Fitzroy River and strategized on how to use power through multiple nation-state based mechanisms. They have found ways to cross scales of institutional responsibilities and negotiate inter-cultural interests, a strategy similarly generating power for other Indigenous nations (Rigney et al. 2015).

Several time-space relations and events shaped the conditions within which the Traditional Owners are responding and collaborating, exercising agency, to negotiate new rules with government and industry to re-install their relationship and responsibilities through water. These events included more than 40 years of the KLC working with Traditional Owners to establish their interests and rights on their lands and waters resulting in new partnerships, capabilities and corporations that are representing Traditional Owner interests (Toussaint et al. 2001; Taylor et al. 2016; Lim and Poelina 2017; Poelina et al. 2019; Poelina 2020). 
Successive years of harmful development impacts, and the government-initiated engagement process for the Fitzroy River management plan, stimulated Traditional Owners to make the Fitzroy River Declaration. This Declaration is an important Indigenous-led innovation where both First Law and the inherent rights of nature have been recognised in an instrument negotiated among different First Peoples groups (Lim and Poelina 2017). Through their knowledge, resource partnerships and deliberative processes at the workshops Traditional Owners identified how to use nation-state instruments of power, to craft knowledge and communication products that cross Indigenous and non-Indigenous boundaries (Rigney et al. 2015; Murray and Burrows 2017). Their notion of the river and its waters having agency and a lifeforce resonates with Indigenous-driven legal changes in India and New Zealand which have recognised rivers as legal entities (O'Donnell and Talbot-Jones 2018).

Traditional Owners' use of the project discussions to further their plans and strategies adds weight to the wider usefulness of knowledge co-production as an arena for stimulating transformative change. The analysis confirmed that the project activities led to most of the envisaged immediate outcomes and confirmed progress on the pathway to the overall impact. While the project was conceived as "showing and sharing knowledge", with and for the Traditional Owner participants, the most important overall result was "learning together". The positionality of the researchers as willing to follow Indigenous leadership, and to work to equalise power relations was a key contributor to the mutual learning (Maclean et al. 2021). Researchers learnt a great deal: about cultural protocols; about the river from the many discussions of cultural sites, tracks, values and perspectives; from the reflection and (re)-planning steps in the action coresearch cycles; about how to communicate effectively with Traditional Owners, and to collaborate in ways that promote mutual respect, equity, mutual benefits and are embedded in their relational ethics of pluralism, reciprocity and care (Milgin et al. 2020). This transition from a project about sharing knowledge to one about learning together is important in light of the recent findings that among Traditional Owners in the Fitzroy catchment, learning generated through Indigenous natural resource management programs is positively associated with life satisfaction measured through a survey instrument, whereas sharing knowledge can be negatively associated, mostly due to sharing in culturally inappropriate exchanges (Jarvis et al. 2021).

The work of the Traditional Owners to organise and mobilise around both their Indigenous and nation-state institutions demonstrate the rebuilding of modern Indigenous governance systems at new hybrid scales of collaboration (Toussaint et al. 2001; Taylor et al. 2016; Lim and Poelina 2017; Poelina et al. 2019; Poelina 2020). As highlighted by Douglas et al. (2019) these hybrid institutions are nested and grounded on Country-based responsibilities-for water, sites, animals and plants-while also engaged in international discourses on conservation and heritage protection, and Aboriginal rights and identity. The modern hybrid Indigenous institutions are strengthening traditional governance (e.g. Kimberley Aboriginal Law and Culture Centre, KLC) while driving the new alliance, the Martuwarra Fitzroy River Council, that has leveraged some financial support from the nation-state, thereby empowering Indigenous institutions for local decision-making and learning.

Co-production between Indigenous and scientific knowledge systems that focuses on visual/tactile spatial knowledge platforms, social learning, and participatory influence mapping, aligned with the Traditional Owner priorities, improves the accessibility of the knowledge, and the experiences of the knowledge users, strengthens collective identity and partnerships, and strengthens indigenous-led institutions. This leads to improved Indigenous environmental planning and management among remote land-attached Indigenous peoples where it is embedded in deliberations led by Indigenous institutions, and where the relationship between the Indigenous and the nation-state institutions empowers local decision-making and learning. Under these conditions, knowledge co-production can support Indigenous leadership for Indigenous futures, through helping to forge the required new relationships based on negotiation, consent, trust, consensus, accountability and reciprocity.

Supplementary Information The online version contains supplementary material available at https://doi.org/10.1007/s11625-021-00988-x.

Acknowledgements This research was supported by a partnership between CSIRO and organisations representing ten Traditional Owner groups in the Fitzroy River catchment: Bunuba, Gooniyandi, Jaru, Kija (including Ngarrawanji and Yurriyangem Taam sub-groups), Kurungal, Nyikina Mangala, Warrwa, Wilinggin, Yi-Martuwarra Ngurrara and Yungngora Peoples. We would like to acknowledge the fine support of Bunuba Dawangarri Aboriginal Corporation, Gooniyandi Aboriginal Corporation, Tiya Tiya Aboriginal Corporation, Walalakoo Aboriginal Corpoation, Wilinggin Aboriginal Corporation, Yanunijarra Aboriginal Corporation, Yungngora Aboriginal Corporation and the Kimberley Land Council. The research for this article was supported with funding from the Australian Government's National Environmental Science Program, CSIRO, James Cook University, and the University of Western Australia. JAR acknowledges the support of the Australian Research Council. We would like to thank the Traditional Owners and Elders for the opportunity to work together on their traditional lands, and for their outstanding contributions to the project. We acknowledge the assistance of reviewers for their incisive comments on earlier drafts. Coauthor Rachel Buissereth was affiliated with CSIRO at the time of the research. The research was conducted under ethics approval 81/16 from the CSIRO Social Science Human Research Ethics Committee.

Open Access This article is licensed under a Creative Commons Attribution 4.0 International License, which permits use, sharing, adaptation, distribution and reproduction in any medium or format, as long as you give appropriate credit to the original author(s) and the source, provide a link to the Creative Commons licence, and indicate if changes 
were made. The images or other third party material in this article are included in the article's Creative Commons licence, unless indicated otherwise in a credit line to the material. If material is not included in the article's Creative Commons licence and your intended use is not permitted by statutory regulation or exceeds the permitted use, you will need to obtain permission directly from the copyright holder. To view a copy of this licence, visit http://creativecommons.org/licenses/by/4.0/.

\section{References}

ABS (2016) 2016 Census of Population and Housing: Mesh Block Counts, Australia.www.abs.gov.au/ausstats/abs@.nsf/mf/2074.0, Accessed 20 February 2021

AIATSIS (2020) AIATSIS Code of Ethics for Aboriginal and Torres Strait Islander Research. Australian Institute of Aboriginal and Torres Strait Islander Studies (AIATSIS), Canberra, Australia. https://aiatsis.gov.au/sites/default/files/2020-10/aiatsis-code-ethics.pdf, Accessed 20 February 2021

Armitage D, Berkes F, Dale A et al (2011) Co-management and the co-production of knowledge: learning to adapt in Canada's Arctic. Glob Environ Chang Policy Dimens 21:995-1004. https://doi.org/ 10.1016/j.gloenvcha.2011.04.006

Avelino F, Rotmans J (2011) A dynamic conceptualization of power for sustainability research. J Clean Prod 19:796-804. https://doi. org/10.1016/j.jclepro.2010.11.012

Banaynal R, Dwamena E (2011) Enhancing food security, climate change and sustainable development planning in Ghana using participatory three dimensional model map. J Sustain Dev Africa 13:155-165

Carr B, Fitzsimons J, Holland N et al (2017) CAPitalising on conservation knowledge: using conservation action planning, healthy country planning and the open standards in Australia. Ecol Manag Restor 18:176-189. https://doi.org/10.1111/emr.12267

Cash DW, Clark WC, Alcock F et al (2003) Knowledge systems for sustainable development. Proc Natl Acad Sci USA 100:8086-8091. https://doi.org/10.1073/pnas.1231332100

Cash DW, Moser SC (2000) Linking global and local scales: designing dynamic assessment and management processes. Glob Environ Chang 10:109-120

Chapman JM, Schott S (2020) Knowledge coevolution: generating new understanding through bridging and strengthening distinct knowledge systems and empowering local knowledge holders. Sustain Sci. https://doi.org/10.1007/s11625-020-00781-2

Coulthard GS (2014) Red skin, white masks: rejecting the colonial politics of recognition. University of Minnesota Press, Minneapolis

Davies HN, Gould J, Hovey R et al (2020) Mapping the marine environment through a cross-cultural collaboration. Front Mar Sci 7:716

Douglas MM, Jackson S, Canham CA et al (2019) Conceptualizing hydro-socio-ecological relationships to enable more integrated and inclusive water allocation planning. One Earth 1:361-373

DPLH (2020) Aboriginal communities and town reserves (DPLH-002) Spatial Dataset. https://www.catalogue.data.wa.gov.au/is/dataset/ aboriginal-communities-and-town-reserves. DPLH, Midland, Accessed 20 Feb 2021

Dunn G, Laing M (2017) Policy-makers perspectives on credibility, relevance and legitimacy (CRELE). Environ Sci Policy 76:146-152. https://doi.org/10.1016/j.envsci.2017.07.005

Ens E, Scott ML, Rangers YM et al (2016) Putting indigenous conservation policy into practice delivers biodiversity and cultural benefits. Biodivers Conserv 25:2889-2906. https://doi.org/10. 1007/s10531-016-1207-6
Fisher R, Heckbert S, Villalobos JML, Sutton S (2019) Augmenting physical 3D models with projected information to support environmental knowledge exchange. Appl Geogr 112:102095

Ford L, Woodward E, Hill R, et al (2020) Actions towards best practice to support Our Knowledge Our Way. In: Our Knowledge Our Way in caring for Country. Indigenous-led approaches to strengthening and sharing our knowledge for land and sea management. Best Practice Guidelines from Australian experiences. NAILSMA and CSIRO, Cairns, Australia. https://www.csiro.au/en/research/indig enous-science/Indigenous-knowledge/Our-Knowledge-Our-Way/ OKOW-resources. Accessed 20 Feb 2021

Fritz L, Meinherz F (2020) Tracing power in transdisciplinary sustainability research: an exploration. Gaia-Ecol Perspect Sci Soc 29:41-51. https://doi.org/10.14512/gaia.29.1.9

Garnett ST, Burgess ND, Fa JE et al (2018) A spatial overview of the global importance of Indigenous lands for conservation. Nat Sustain 1:369-374. https://doi.org/10.1038/s41893-018-0100-6

GoWA (2020) Managing water in the Fitzroy River Catchment Discussion paper for stakeholder consultation. Government of Western Australia, Perth, Australia. https://www.water.wa.gov.au/_data/assets/pdf_file/ 0016/10087/115885.pdf, Accessed 20 February 2021

Griffiths S, Kinnane S, (KLRC) KLRC (2011) The Kimberley Aboriginal Caring for Country Plan. Nulungu Centre for Indigenous Studies (NCIS), The University of Notre Dame, Broome, WA, Australia

Guillemette M, Potvin C, Martinez L et al (2017) Building a common description of land cover in a tropical watershed plagued with intercultural conflicts: the value of participatory 3D modelling. Facets 2:195-211. https://doi.org/10.1139/facets-2016-0010

Hauck J, Stein C, Schiffer E, Vandewalle M (2015) Seeing the forest and the trees: facilitating participatory network planning in environmental governance. Glob Environ Chang 35:400-410. https:// doi.org/10.1016/j.gloenvcha.2015.09.022

Hemming S, Rigney D, Muller SL et al (2017) A new direction for water management? Indigenous nation building as a strategy for river health. Ecol Soc 22:13

Hill R, Miller C, Newell B, Dunlop M, Gordon IJ (2015) Why biodiversity declines as protected areas increase: the effect of the power of governance regimes on sustainable landscapes. Sustainability Science 10(2):357-369. https://doi.org/10.1007/s11625-015-0288-6

Hill R, Lyons I, George M, Biggs K (2016) Country: multiple values, multiple benefits into the future. Research priorities for Indigenous Protected Areas across northern Australia. CSIRO Land and Water, Online: https://publications.csiro.au/rpr/download?pid= csiro:EP163599\&dsid=DS3, Accessed 20 June 2021

Hill R, Walsh F, Davies J et al (2020) Knowledge co-production for Indigenous adaptation pathways: transform post-colonial articulation complexes to empower local decision-making. Glob Environ Chang 65:102161. https://doi.org/10.1016/j.gloenvcha.2020. 102161

Jackson S (2018) Water and Indigenous rights: Mechanisms and pathways of recognition, representation, and redistribution. WIREs Water 5:1314. https://doi.org/10.1002/wat2.1314

Jackson S (2015) Indigenous social and cultural values relating to water in the Fitzroy Valley, Kimberley (WA): information availability, knowledge gaps and research needs. Australian Rivers Institute, Griffith University, Nathan, QLD

Jackson S, Finn M, Featherston P (2012) Aquatic resource use by Indigenous Australians in two tropical river catchments: the Fitzroy River and Daly River. Hum Ecol 40:893-908. https:// doi.org/10.1007/s10745-012-9518-Z

Jackson S, Finn M, Scheepers K (2014) The use of replacement cost method to assess and manage the impacts of water resource development on Australian indigenous customary economies. J Environ Manag 135:100-109. https://doi.org/10.1016/j.jenvm an.2014.01.018 
Jarvis D, Stoeckl N, Addison J et al (2018) Are Indigenous land and sea management programs a pathway to indigenous economic independence? Rangel J 40:415-429. https://doi.org/10.1071/ RJ18051

Jarvis D, Stoeckl N, Larson S et al (2021) The learning generated through Indigenous natural resources management programs greatly increases the life satisfaction of Indigenous people. Ecol Econ 180:106899

Jasanoff S (2004) States of knowledge. In: Jasanoff S (ed) Ordering knowledge, ordering society. Routledge, New York, USA and London, UK, pp 13-45

Johnson JT, Cant G, Howitt R, Peters E (2007) Creating anti-colonial geographies: embracing indigenous peoples' knowledges and rights. Geogr Res 45:117-120. https://doi.org/10.1111/j.17455871.2007.00441.x

Kim MK, Álvarez-Romero JG, Wallace KJ, et al (2021, in review) Participatory multi-stakeholder assessment of alternative development scenarios in contested landscapes. Sust. Sci.

Latulippe N, Klenk N (2020) Making room and moving over: knowledge co-production, indigenous knowledge sovereignty and the politics of global environmental change decision-making. Curr Opin Environ Sustain 42:7-14

Lebel L, Grothmann T, Siebenhüner B (2010) The role of social learning in adaptiveness: Insights from water management. Int Environ Agreements Polit Law Econ 10:333-353. https://doi.org/10.1007/ s10784-010-9142-6

Leys AJ, Vanclay JK (2011) Social learning: a knowledge and capacity building approach for adaptive co-management of contested landscapes. Land Use Policy 28:574-584. https://doi.org/10.1016/j. landusepol.2010.11.006

Likert R (1932) A technique for the measurement of attitudes. Arch Psychol 22(140):55

Lim M, Poelina A, Bagnall DJAER (2017) Can the Fitzroy River Declaration ensure the realisation of the First Laws of the River and secure sustainable and equitable futures for the West Kimberley? Aust Environ Rev 32:18-24

Louis RP (2007) Can you hear us now? Voices from the margin: using indigenous methodologies in geographic research. Geogr Res 45:130-139. https://doi.org/10.1111/j.1745-5871.2007.00443.x

Maclean K, Woodward E, Jarvis D, Turpin G, Rowland D, Rist P. (2021) Decolonising knowledge co-production: examining the role of positionality and partnerships to support Indigenousled bush product enterprises in northern Australia. Sustain Sci. https://doi.org/10.1007/s11625-021-00973-4

Maloney T, O'Connor S, Wood R et al (2018) Carpenters gap 1: a 47,000 year old record of indigenous adaption and innovation. Quat Sci Rev 191:204-228. https://doi.org/10.1016/j.quascirev. 2018.05.016

McGregor W (2004) The languages of the Kimberley Western Australia. RoutledgeCurzon, New York

McKemey M, Ens E, Rangers YM et al (2020) Indigenous knowledge and seasonal calendar inform adaptive savanna burning in northern Australia. Sustainability 12:995

Metcalfe DJ, Bui EN (2017) Australia State of the Environment 2016 Land. Independent report to the Australian Government Minister for the Environment and Energy, Australian Government Department of the Environment and Energy, Canberra, Australia. Online: https://doi.org/10.4226/94/58b6585f94911

Milgin A, Nardea L, Grey H et al (2020) Sustainability crises are crises of relationship: learning from Nyikina ecology and ethics. People Nat 2:1210-1222. https://doi.org/10.1002/pan3.10149

Mistry J, Berardi A (2016) Bridging indigenous and scientific knowledge. Science (80-) 352:1274-1275. https://doi.org/10.1126/scien ce.aaf 1160
Muro M, Jeffrey P (2008) A critical review of the theory and application of social learning in participatory natural resource management processes. J Environ Plan Manag 51:325-344

Murray G, Burrows D (2017) Understanding power in indigenous protected areas: the case of the Tla-o-qui-aht tribal parks. Hum Ecol 45:763-772. https://doi.org/10.1007/s10745-017-9948-8

Natcher D, Owens-Beek N, Bogdan A-M, Lu X, Ingram S, McKay R, Rice, A. (2021) Scenario planning tools for mitigating industrial impacts on First Nations subsistence economies in British Columbia, Canada. Sustain Sci. https://doi.org/10.1007/ s11625-021-00969-0

O'Donnell EL, Talbot-Jones J (2018) Creating legal rights for rivers: lessons from Australia, New Zealand, and India. Ecol Soc. https:// doi.org/10.5751/es-09854-230107

Pansardi P (2012) Power to and power over: two distinct concepts of power? J Polit Power 5:73-89. https://doi.org/10.1080/2158379X 2012.658278

Pereira LM, Hichert T, Hamann M et al (2018) Using futures methods to create transformative spaces: visions of a good Anthropocene in southern Africa. Ecol Soc 23:13. https://doi.org/10.5751/ es-09907-230119

Petheram C, Bruce C, Chilcott C, Watson I (2018) Water resource assessment for the Fitzroy catchment. A report to the Australian Government from the CSIRO Northern Australia Water Resource Assessment, part of the National Water Infrastructure Development Fund: Water Resource Assessments. CSIRO, Australia

Poelina A (2020) A coalition of hope! A regional governance approach to indigenous Australian cultural wellbeing. In: Campbell A, Duffy M, Edmondson B (eds) Located research: regional places, transitions and challenges. Springer, Singapore, pp 153-180

Poelina A, Taylor KS, Perdrisat I (2019) Martuwarra Fitzroy River Council: an Indigenous cultural approach to collaborative water governance. Australas J Environ Manag 26:236-254

Poelina A, Webb T, Dhimurru Aboriginal Corporation, et al (2020) Foundations of our knowledge our way. In: Woodward E, Hill R, Harkness P Archer R (eds) Our knowledge our way in caring for country. Indigenous-led approaches to strengthening and sharing our knowledge for land and sea management. Best Practice Guidelines from Australian experiences. NAILSMA and CSIRO, Cairns, Australia, pp 1-20. https://www.csiro.au/en/research/indig enous-science/Indigenous-knowledge/Our-Knowledge-Our-Way/ OKOW-resources. Accessed 20 Feb 2021

Rambaldi G, Muchemi J, Crawhall N, Monaci L (2007) Through the eyes of hunter-gatherers: participatory 3D modelling among Ogiek indigenous peoples in Kenya. Inf Dev 23:113-128

Raymond CM, Giusti M, Barthel S (2018) An embodied perspective on the co-production of cultural ecosystem services: toward embodied ecosystems. J Environ Plan Manag 61:778-799. https://doi. org/10.1080/09640568.2017.1312300

Reed MS, Evely AC, Cundill G et al (2010) What is social learning? Ecol Soc. https://doi.org/10.5751/ES-03564-1504r01

Rigney D, Bignall S, Hemming S (2015) Negotiating Indigenous Modernity: Kungun Ngarrindjeri Yunnan-listen to Ngarrindjeri speak. Altern an Int J Indig Peoples 11:334-349. https://doi.org/ 10.1177/117718011501100402

Roux DJ, Nel JL, Cundill G et al (2017) Transdisciplinary research for systemic change: who to learn with, what to learn about and how to learn. Sustain Sci 12:711-726. https://doi.org/10.1007/ s11625-017-0446-0

Schiffer E, Hauck J (2010) Net-Map: collecting social network data and facilitating network learning through participatory influence network mapping. Field Methods 22:231-249

Schneider F, Giger M, Harari N et al (2019) Transdisciplinary coproduction of knowledge and sustainability transformations: three generic mechanisms of impact generation. Environ Sci Policy 102:26-35. https://doi.org/10.1016/j.envsci.2019.08.017 
Smith LT (1999) Decolonizing methodologies: research and indigenous peoples. Zed Books Ltd and the University of Otago Press, London and Dunedin

Taylor KS, Moggridge BJ, Poelina A (2016) Australian Indigenous Water Policy and the impacts of the ever-changing political cycle. Australas J Water Resour 20:132-147. https://doi.org/10.1080/ 13241583.2017.1348887

Tobias TN (2000) Chief Kerry's moose: a guidebook to land use and occupancy mapping, research design, and data collection. A joint publication of the Union of BC Indian Chiefs and Ecotrust Canada, Vancouver

Toussaint S, Sullivan P, Yu S, Mularty M (2001) Fitzroy valley indigenous cultural values study (a preliminary assessment). Centre for Anthropological Research, The University of Western Australia, Nedlands

Traditional Owners and Researchers (2018) Showing and sharing knowledge: supporting traditional owner decision-making. National Environmental Science Program Northern Australia Environmental Resources Hub, Online: https://www.nespnorthe rn.edu.au/projects/nesp/knowledge-brokering-indigenous-landmanagement/, Accessed 20 June 2021

Tschirhart C, Mistry J, Berardi A et al (2016) Learning from one another: evaluating the impact of horizontal knowledge exchange for environmental management and governance. Ecol Soc 21:14. https://doi.org/10.5751/es-08495-210241

Vigilante T (2001) Analysis of explorers' records of aboriginal landscape burning in the Kimberley region of Western Australia. Aust Geogr Stud 39:135-155. https://doi.org/10.1111/1467-8470. 00136
Wheeler HC, Root-Bernstein M (2020) Informing decision-making with Indigenous and local knowledge and science. J Appl Ecol $57: 1634-1643$

Whyte K (2020) Too late for indigenous climate justice: ecological and relational tipping points. Wires Clim Chang 11:e603. https://doi. org $/ 10.1002 /$ wcc.603

Wilson S (2008) Research is ceremony. Indigenous research methods. Fernwood Publishing, Black Point

Wolfe P (2006) Settler colonialism and the elimination of the native. J Genocide Res 8:387-409

Woodward E, McTaggart PM (2016) Transforming cross-cultural water research through trust, participation and place. Geogr Res 54:129-142. https://doi.org/10.1111/1745-5871.12136

Wyborn C, Datta A, Montana J et al (2019) Co-producing sustainability: reordering the governance of science, policy, and practice. Annu Rev Environ Resour 44:319-346. https://doi.org/10.1146/ annurev-environ-101718-033103

Zurba M, Maclean K, Woodward E, Islam D (2019) Amplifying Indigenous community participation in place-based research through boundary work. Prog Hum Geogr 43:1020-1043. https://doi.org/ 10.1177/0309132518807758

Zurba M, Maclean K, Woodward E, Islam D (2018) Amplifying Indigenous community participation in place-based research through boundary work. Prog Hum Geogr. https://doi.org/10.1177/03091 32518807758

Publisher's Note Springer Nature remains neutral with regard to jurisdictional claims in published maps and institutional affiliations.

\section{Authors and Affiliations}

Rosemary Hill $^{1,2}$ (D) Pia Harkness ${ }^{1} \cdot$ Nat Raisbeck-Brown ${ }^{1} \cdot$ Ilisapeci Lyons ${ }^{1} \cdot$ Jorge G. Álvarez-Romero ${ }^{2}$. Milena Kiatkoski $\mathrm{Kim}^{3}$. Dennis Chungalla ${ }^{4}$. Heather Wungundin ${ }^{4} \cdot$ Mary Aiken $^{4}$. Jean Malay ${ }^{4}$.

Bernadette Williams ${ }^{4} \cdot$ Rachel Buissereth ${ }^{5} \cdot$ Tim Cranbell $^{4} \cdot$ Josephine Forrest ${ }^{4} \cdot$ Marmingee Hand $^{4} \cdot$ Ross James $^{4}$. Elizabeth Jingle ${ }^{4}$. Olive Knight ${ }^{4,6} \cdot$ Nathan Lennard $^{4}$ • Valerie Lennard ${ }^{4}$. Ileen Malay ${ }^{4}$ Lindsay Malay ${ }^{4}$. Wallace Midmee ${ }^{4}$ Stuart Morton ${ }^{4} \cdot$ Chloe Nulgit $^{4} \cdot$ Patricia Riley ${ }^{4} \cdot$ Ina Shadforth ${ }^{4}$. Jane Bieundurry ${ }^{4}$. George Brooking ${ }^{4}$. Sherika Brooking ${ }^{4}$. Willy Brumby ${ }^{4} \cdot$ Victor Bulmer $^{4}$. Virgil Cherel ${ }^{4}$. Ashley Clifton ${ }^{4}$. Sam Cox ${ }^{4} \cdot$ Matt Dawson $^{4}$. Cissy Gore-Birch ${ }^{4}$. John Hill ${ }^{5}$. Alistair Hobbs ${ }^{4}$. Duran Hobbs ${ }^{4}$. Camelia Juboy ${ }^{4}$. Patricia Juboy ${ }^{4} \cdot$ Annette Kogolo $^{4} \cdot$ Sarah Laborde $^{7} \cdot$ Barry Lennard $^{4} \cdot$ Con Lennard $^{4}$. Deon Lennard ${ }^{4}$. Nelita Malay ${ }^{4} \cdot$ Zenneth Malay ${ }^{4} \cdot$ David Marshall ${ }^{4} \cdot$ Herbert Marshall ${ }^{4} \cdot$ Lezeka Millindee $^{4} \cdot$ Diane Mowaljarlai $^{4}$. Andrea Myers ${ }^{4} \cdot$ Thomas Nnarda $^{4} \cdot$ Joy Nuggett ${ }^{4} \cdot$ Lloyd Nulgit $^{4} \cdot$ Pansy Nulgit ${ }^{4}$. Anne Poelina ${ }^{4} \cdot$ Daniel Poudrill $^{4}$. Joe Ross ${ }^{4}$. Jimmy Shandley ${ }^{4}$ Roly Skander ${ }^{5}$. Sandy Skeen ${ }^{4}$. Gordon Smith ${ }^{4}$. Mervyn Street ${ }^{4} \cdot$ Pauline Thomas ${ }^{4}$.

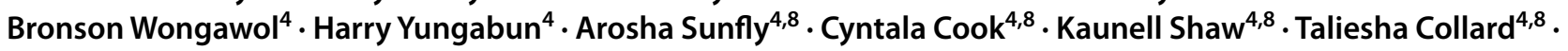
Yvonne Collard ${ }^{4,8}$

Rosemary Hill

ro.hill@csiro.au

1 CSIRO, Cairns, Australia

2 James Cook University Division of Tropical Environment and Societies, Cairns and ARC Centre of Excellence for Coral Reef Studies, Townsville, Australia

3 University of Western Australia, Crawley, Australia
4 Traditional Owner From the Fitzroy River Catchment, Fitzroy River, Australia

5 Independent Consultant, Perth, Australia

6 Interpreter, Fitzroy Crossing, Australia

7 Griffith University, Brisbane, Australia

8 Student from the Fitzroy Valley District High School, Fitzroy Crossing, Australia 